\title{
Research on the Quaternary fluvial geomorphological surface sequence of the foreland region in southern Longmen Shan, eastern Tibet
}

\author{
Dawei Jiang a Shimin Zhang ${ }^{b^{*}}$ Wei Li ${ }^{b}$

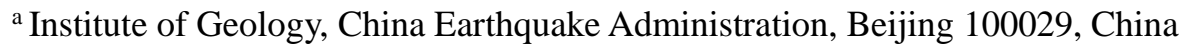 \\ ${ }^{\mathrm{b}}$ Institute of Crustal Dynamics, China Earthquake Administration, Beijing 100085, China \\ *Corresponding author Tel.:+86 1062842643 \\ E-mail: jiangdawei12@163.com
}

\begin{abstract}
Research on the complex structure of the Longmen Shan foreland is of great significance for understanding the tectonism of the eastern Tibetan Plateau. Therefore, using field survey of abandoned alluvial fans that developed during the middle Pleistocene and the terraces of the modern Qingyi River, a geomorphological surface sequence for the foreland region was established to study the tectonic surface processes. We know that the deformations of river terraces can serve as foundations for the study of tectonic activity. Because the Qingyi River ran through the foreland region in the south range of Longmen Shan, it is an appropriate research area and was adopted to solve these problems. However, in the humid temperate region, the terraces are strongly eroded and hardly retain continuous morphological surfaces. In addition, no marker horizons are available that can be utilized to restrain the corresponding relationships among terraces at the same level. To solve these problems, high-precision field measurements of the terraces and alluvial fan were made, and a series of long cross sections were acquired to determine the spatial relationships between the geomorphological surfaces; moreover, based on major element tests and grain size analyses, we found that the sediments of the geomorphological surfaces at all levels had favorable corresponding relationships. Using those specific analyses of
\end{abstract}


geomorphological surfaces and sediments, a geomorphological surface sequence was derived for the foreland region. The surface sequence can be employed to study the tectonism of the foreland region over larger spatial and temporal ranges rather than using the limited modern terraces. In addition, after the ages of the geomorphological surfaces at various levels were further tested, the evolution of Qingyi River especially its two migrations since the middle Pleistocene in the foreland was determined.

Keywords: Longmen Shan; geomorphological surface sequence; river migration; bulk element Abbreviations: LQSA, Longquanshan anticline; XPA, Xiongpo anticline; SSCA, Sansuchang
anticline; MQF, Mingshan-Qionglai alluvial fan; DSF, Danling-Simeng alluvial fan; DSF1, early
phase DSF; DSF2, terminal phase DSF; Q2, middle Pleistocene stratum; N, Neogene stratum.

\section{Introduction}

The foreland region in the southern section of Longmen Shan has a complex structure and multiple foreland folds, such as the Xiongpo anticline, Sansuchang anticline, and Longquanshan anticline, that developed there. If the activities of those structures can be explicated, they will have significant implications for research on Longmen Shan. Because the Qingyi River runs through the foreland region in the southern section, river terrace research is suitable for studying tectonic activity. River terraces log the course of the evolution and migration of rivers; therefore, they are frequently used to restore the altitudes and locations of rivers in geological history (England and Molnar, 1990; Burbank et al., 1996; Pan et al., 2003). In addition, research on the deformation of river terraces and corresponding sediments during different periods can reveal the history of a region's tectonic activity and the changes in the characteristics of the geology and climate. They have been extensively applied in a large number of studies of different geological areas (Burbank 
et al., 1988; Lavé and Avouac, 2000; Poisson et al., 2004; Ota et al., 2009; He et al., 2015).

After a river runs out from the mountain outlet and enters the foreland region, the slope gradient becomes predominantly gentle, and transportation in the middle reaches of the river is replaced with primary accumulation in its downstream reaches. As a result, rivers in foreland regions are usually developed within alluvial fans; in addition, the older alluvial fans are sliced by rivers at the mountain outlet, and new terraces are formed (Decelles et al., 1996; Horton et al., 2001; Viseras et al., 2003; Harvey et al., 2005). In areas where tectonic activity is rather strong, alluvial fans formed earlier almost completely vanish because of the late erosion of rivers caused by their powerful downcutting, and only a very small part of the alluvial fans remains. Nevertheless, in the foreland region of the southern section of Longmen Shan, an atypical river morphology can be observed. Specifically, the old alluvial fan has been abandoned on the eastern side to the north of the modern Qingyi River because of river migration (Zhang et al., 1982, 2000; Deng et al., 2009). As a result, an alluvial upland with an area of over $2000 \mathrm{~km}^{2}$ has formed. Furthermore, the upland is comprised of a gravel layer whose thickness ranges from 50 to $150 \mathrm{~m}$.

Multiple ancient river geomorphological surfaces are preserved on the abandoned alluvial fan; their distribution patterns, extension heights, and other features are closely related to the river terraces on either side of the modern Qingyi River. We have attempted to establish a geomorphological surface sequence for the ancient multiphase alluvial fan together with the modern Qingyi River terrace. The geomorphological surface sequence can be used to describe the Qingyi River's migration. In addition, deformation of the geomorphological surface in the sequence is available to study the tectonic activity of southern Longmen Shan.

A field survey and high-precision measurements were used to research the range and altitude 
of each morphological surface. Moreover, to recognize distinctions between morphological surfaces, outcrops were surveyed to study depositional characteristics. Furthermore, bulk elements were tested to distinguish chemical weathering, and grain sizes were tested to describe physical features.

\section{Geological setting}

Strong thrust uplift occurred in the nappe tectonic belt of Longmen Shan during the collision of the Cenozoic Indian Plate and the Eurasian Plate, and it became the eastern boundary of the Tibetan Plateau. Longmen Shan has received ongoing attention because of its steep terrain and the serious geological disasters that have occurred there (Parsons et al., 2008; Xu et al., 2009; Hubbard et al., 2009; Zhang et al., 2010, 2013). The deep structure, topography, landforms, and other characteristics of the Longmen Shan tectonic zone have often been studied by other researchers (Zhang et al., 2009; Jia et al., 2010; Li et al., 2010; Guo et al., 2013; Zhang, 2013), and research on the river and surfaces has also progressed (Ma et al., 2005; Zhang et al., 2010; Liu et al., 2015). However, the landform of the foreland region has rarely been systematically studied, excluding the Longquanshan anticline (LQSA; Li et al., 2015; Fig. 1A).

The most recent foreland basin in the Longmen Shan Nappe tectonic belt is the Chengdu plain, and the eastern boundary of the foreland system is the Longquanshan anticline (Fig. 1A). Although the foreland region on the northern section of Longmen Shan is flat, the southern section has a very complex structure: besides the Longquanshan anticline, two folds, the Xiongpo anticline (XPA) and the Sansuchang anticline (SSCA), developed there (Fig. 1B). Originating from the Baoxing-Tianquan-Yingjing district upstream, the tributaries of the Qingyi River include the Zhougong River, Yingjing River, Tianquan River, and Yuxi River; and the Qingyi River flows 
to Leshan city through Hongya county and Jiajiang county in the southeast from the mountain outlet in Yaan city. In the foreland region, an ancient alluvial fan formed by gravels of a middle Pleistocene series has been widely developed and is also well preserved (Fig. 1B). Mainly two research objects are discussed in this paper. One is the abandoned ancient alluvial fan, which includes the Mingshan-Qionglai fan (MQF) and Danling-Simeng fan (DSF), and the other is the river terrace on both sides of the modern Qingyi River (Fig. 1B). To make the description brief, abbreviations are used in the following paragraphs and figures, the details of which are shown in the front page footnote.

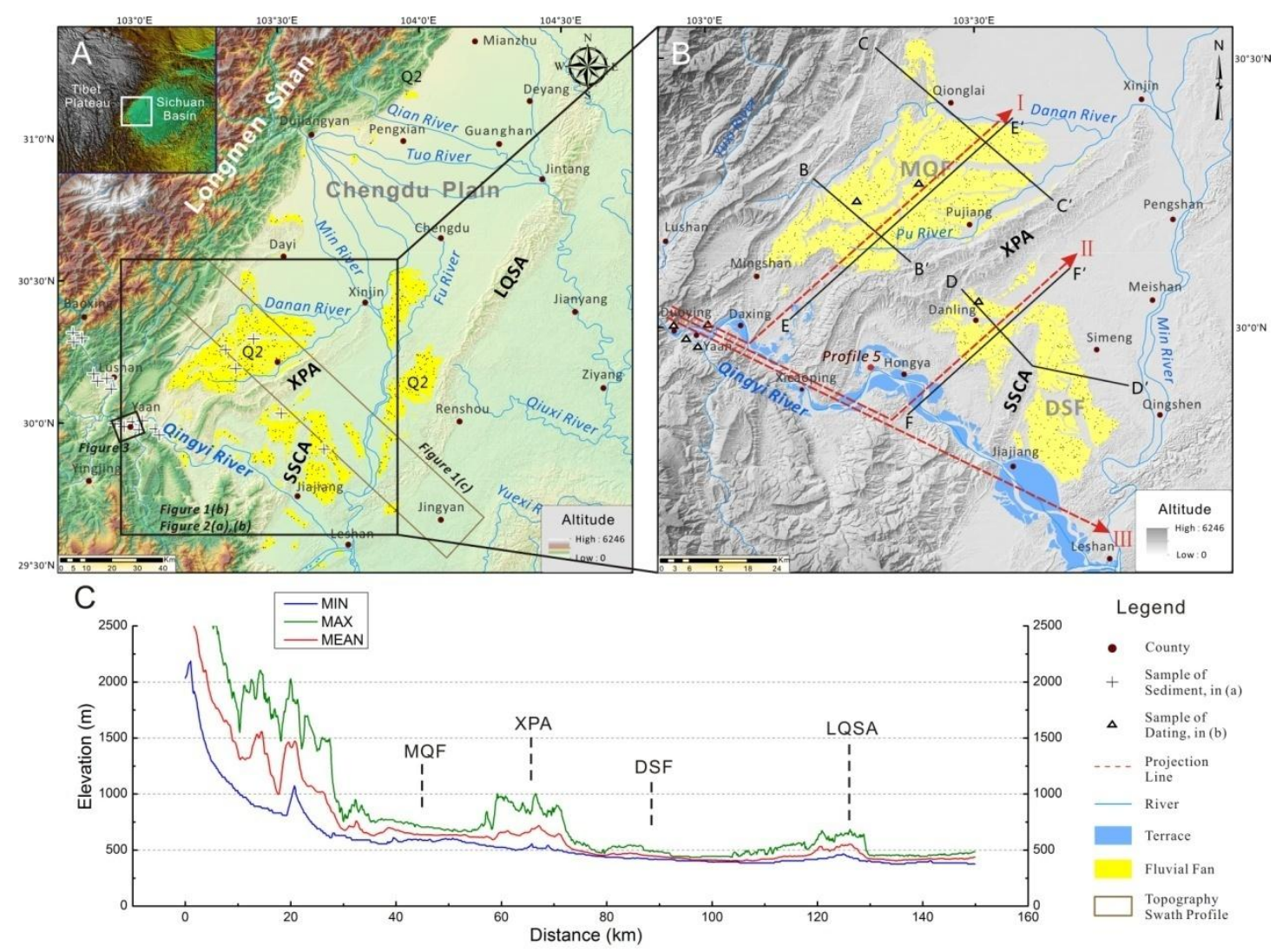

Fig. 1. Regional structure of Longmen Shan and the topography of the study area. (A) Longmen Shan and the foreland region; (B) distribution diagram of the river's geomorphological surface in the southern section of Longmen Shan, whose range is shown in (A); (C) shows a topographic cross section for the banded terrain in the foreland region of the southern Longmen Shan, whose coverage area is shown in (A). 


\subsection{Alluvial fan}

A middle Pleistocene series gravel stratum forms the main body of the abandoned alluvial fan in the foreland region of the research area, which can be divided into two parts topographically. One is the Mingshan-Qionglai alluvial fan (MQF) between Longmen Shan and the XPA (Zhang et al., 1982; Figs. 1A, 1B), and the other is the Danling-Simeng alluvial fan (DSF) between APX and Longmen Shan (Zhang et al., 2000; Figs. 1A, 1B). According to the belted topographic cross section covering the foreland region in southern Longmen Shan (Fig. 1C), we see that the DSF is isolated topographically from the MQF by the XPA.

\subsection{1. $M Q F$}

Located between Longmen Shan and the XPA, the MQF horizontal distribution begins from Mingshan county and extends ENE toward the fan edge west of Qionglai city (Fig. 1B). The head of the fan in the west is situated in Mingshan county (at an altitude of $772 \mathrm{~m}$ ), whereas the eastern fan edge is situated along a line from Qionglai to Xinjin (at an altitude of $488 \mathrm{~m}$ ); moreover, it reaches the northeast mountain ridge in Pingle town (at an altitude of $497 \mathrm{~m}$ ) in the north; and in Pujiang county, it reaches the northern slope of the XPA in the south (at an altitude of $583 \mathrm{~m}$ ). In the lengthwise direction, it is as long as $56 \mathrm{~km}$, its leading edge has a width of $\sim 24 \mathrm{~km}$, and the distribution area is $1050 \mathrm{~km}^{2}$. From Wangu at the fan head to the fan edge, the slope is $\sim 0.51 \%$. The slope gradient of the fan sector is $\sim 0.29^{\circ}$, and the sedimentary thickness ranges from 50 to $150 \mathrm{~m}$.

According to previous research, the composition of MQF conforms to the Proterozoic stratum that is extensively distributed in the Baoxing-Tianquan-Yingjing district upstream of the Qingyi 
River, and it is different from the terrigenous composition of the large-sized intermediate-acidic intrusive rocks in the upper reaches of the Min River. Therefore, they are judged to be fluvial deposits of the ancient Qingyi River (Zhang et al., 1982; Yuan et al., 2008; Cui et al., 2009). At present, they have been strongly weathered. Of all the gravels, the quartz and feldspar are still very hard; the majority of the igneous and sedimentary rocks have already been weathered and broken. Matrix such as fluvial sand between gravels has primarily weathered into clay (Fig. 2E).

The color of the matrix clay close to the ground ( $2 \mathrm{~m}$ deep, the following outcrop descriptions are the same) is reddish-brown, and its Munsell color is $2.5 \mathrm{YR} 4 / 8^{1}$ (Fig. 2E, profile M1).
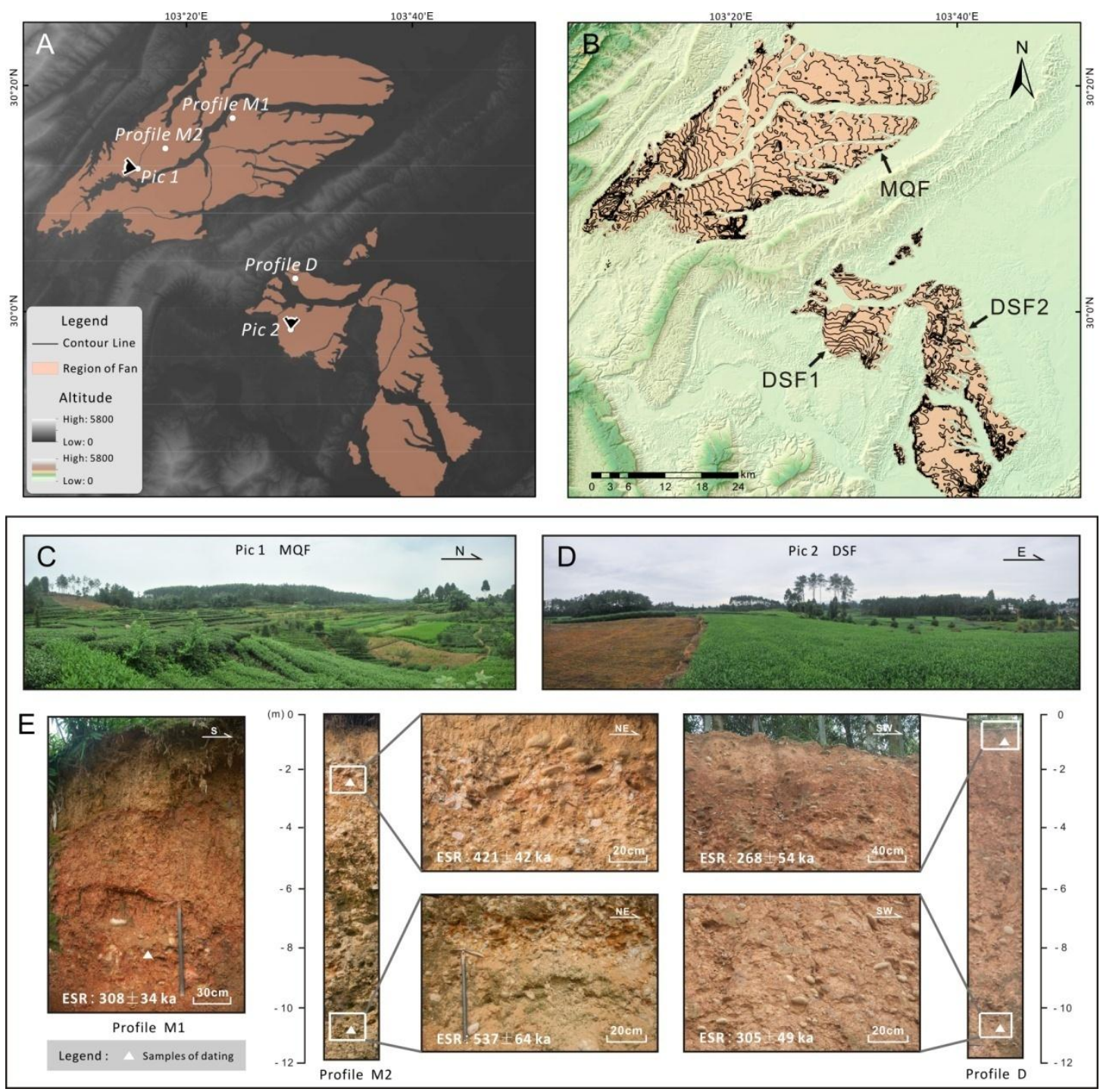

\footnotetext{
${ }^{1}$ Munsell Soil Color (Munsell color, 2013) is adopted as the color standard in this paper.
} 
Fig. 2. Restoration of the alluvial fan sector and its sedimentary characteristics. (A) The DEM used for clipping

and for the locations of the profile and pictures; (B) the contour line after restoration; (C) morphological picture of the MQF, the location of the sight view is shown in (A); (D) morphological picture of the DSF, the location of sight view is shown in (A); (E) picture of the outcrops and the positions of the dating samples, including profile M1, profile M2, and profile D. The position of profiles is shown in (A).

\subsection{2. $D S F$}

The DSF's distribution pattern is fan-shaped and spreads from west to east (Fig. 2B). It starts from Hongya county in the west (at an altitude of $662 \mathrm{~m}$ ) and goes toward Meishan city in the east (at an altitude of $443 \mathrm{~m}$ ) and Jiajiang county in the south (at an altitude of $460 \mathrm{~m}$; Zhang et al., 2000). In the lengthwise direction, it is as long as $34 \mathrm{~km}$, its leading edge has a width of $\sim 28 \mathrm{~km}$ and its distribution area is $700 \mathrm{~km}^{2}$. From the fan head to the fan edge, the slope is $0.57-0.64 \%$; moreover, the slope gradient of the fan sector is $\sim 0.35^{\circ}$, and the sedimentary thickness ranges from 30 to $100 \mathrm{~m}$. To the west of Danling county, the DSF gravel bed is distributed sporadically and has suffered serious erosion; on its eastern side, however, the gravel bed becomes distributed in a sheet.

According to a survey of the gravel composition in the DSF, the depositions share some resemblance to the MQF and the modern terrace sediments of the Qingyi River; but they are significantly different from the river sedimentary strata in the Minjiang River basin (Zhang et al., 2000; Cui, 2009). Therefore, we can deduce that the DSF is also an ancient alluvial fan of the Qingyi River. We can see from DSF outcrops that the matrix sand between the gravels has also been weathered into clay. The color of the DSF's matrix is lighter than red, and its Munsell color is $2.5 \mathrm{YR} 4 / 6$ (Fig. 2E, profile D). Moreover, despite a minor color diversity of the matrix clay, the 
sedimentary characteristic of MQF and DSF are very similar to each other.

\subsubsection{Surface restoration}

Because of the humid climate in the Longmen Shan foreland, the ancient landform of the alluvial fan is difficult to determine as a consequence of continuous erosion. In addition, the surface of the fans is carved by ravines and gullies (Fig. 2A). Even on smooth ground, the surface is undulatory (Figs. 2C, 2D).

However, on the whole, the tendency of variation of the pluvial sector is still preserved, thanks to which we have been able to restore the ancient landform surface (Fig. 2A) using a digital elevation model (DEM) with a resolution of $25 \mathrm{~m}$ to further analyze the terrain in its ancient state. Firstly, to avoid disturbances from the surrounding terrain, digital elevations within the scope of the corresponding terrain were extracted from the DEM. Secondly, to eliminate gullies formed by erosion, a grid with a resolution of $200 \mathrm{~m}$ was adopted to perform the elevation extraction of the surface of the platform. Thirdly, the highest point preserved in each grid was extracted, and an interpolation was again performed. Fourthly, the elevation model after interpolation was utilized to generate isograms with an interval of $10 \mathrm{~m}$, and smoothing was performed. As a result, a contour map (Fig. 2B) that represents the ancient landform surface morphology was developed. In line with the restored contour lines, we can clearly see that both the MQF and DSF preserved their own sector forms, although certain changes have occurred along the sector (Fig. 2B).

\subsection{River terraces}

In the foreland basin of Longmen Shan, six terraces of different levels along the Qingyi River are preserved; in ascending order, they are T1, T2, T3, T4, T5, and T6 (Figs. 3A, 3B). Terraces T1 
$\sim \mathrm{T} 4$ are basin wide terraces, but T5 and T6 are local terraces. In addition, the Yaan valley is used as an example (position is shown in Fig. 1A) to introduce the terraces. The terrace surface near Yucheng District and Daxing town of Yaan city is flat and wide (Fig. 3A). The continuities of terraces T1 and T2, which developed on both sides, are rather good. Moreover, although T3 is well preserved on the right bank, T4 is rarely preserved in general. Terraces $\mathrm{T} 1$ and $\mathrm{T} 2$ are accumulation terraces; T3 and T4 are strath terraces. Moreover, the heights of the leading edges of the terraces above the modern riverbed are $4.9 \sim 8.5 \mathrm{~m}$ for T1, $15.2 \sim 18.6 \mathrm{~m}$ for T2, $48.0 \sim 59.9 \mathrm{~m}$ for T3, $88.1 \sim 92.1 \mathrm{~m}$ for T4, $130.1 \sim 150.8 \mathrm{~m}$ for T5, and $204.3 \sim 209.1 \mathrm{~m}$ for T6 (Fig. 3B).

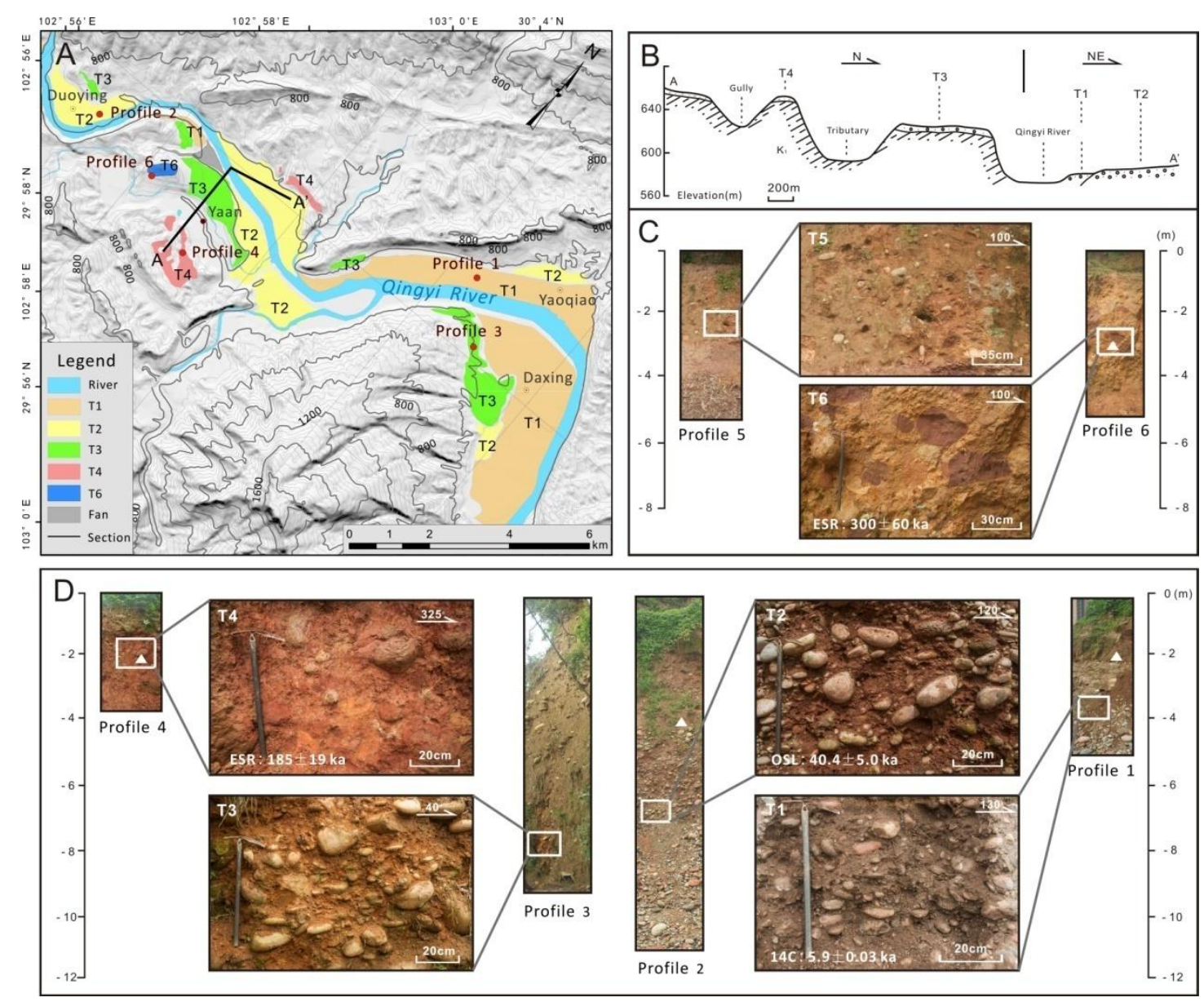


Fig. 3. Terrace morphology and sedimentary characteristics of the modern Qingyi River. The samples' legends are the same as those in Fig. 2. (A) The distribution diagram of the Yaan River valley terrace; (B) the terrace profile whose location is shown in (A) as A-A'; (C) represents the profiles of T5 and T6, and their profile positions have been marked in Figs. 1B and 2A, respectively; (D) the profiles of terraces T1-T4, whose positions have been marked in (A). The legends of (C) and (D) are the same as those of Fig. 2.

The T6 terrace is only preserved at the top of Longgang Mountain, which is situated on the right bank of the Qingyi River southwest of Yaan city (Fig. 3A, profile 6). The visble sedimentary strata are as thick as $5.6 \mathrm{~m}$ (the total thickness of the gravels above the strath is $11.2 \mathrm{~m}$; Fig. 3C), and the sediments are primarily comprised of large quartzite and mudstone gravels with diameters that range from 8 to $35 \mathrm{~cm}$. The matrix between the gravels is clay that has a color of $2.5 \mathrm{YR} 4 / 6$, which is similar to the matrix color of alluvial fan.

Terrace T5 is located near where the Qingyi River runs through the XPA and lies on both sides of the Hongya valley downstream (Fig. 1B, profile 5). The thickness of the sediments in the Xicaoping terrace is $41.3 \mathrm{~m}$, and the exposed thickness is $5.2 \mathrm{~m}$ (Fig. 3C). The gravels in the profile are comprised of quartzite, sandstone, and mudstone with a small quantity of magmatic rocks; they have been substantially weathered. The matrix between the gravels has been weathered into clays and has a color of 2.5YR3/6 (Fig. 3C).

Terrace T4 is mainly preserved on the south bank of the Qingyi River on the piedmont south of the Sichuan Agriculture University and is several hundred meters wide (Fig. 3A, profile 4). To the northwest of Zhangjiaping village the terrace tread near the front edge is $88.1 \pm 2.0 \mathrm{~m}$ above the present river. At the front edge, a 3.5-m-thick brownish red, sandy clay layer mixed with gravels can be seen on top of the alluvial veneer (Fig. 3D); the gravels of diameter $5 \sim 60 \mathrm{~cm}$ are rounded 
or subrounded and are mainly comprised of sandstone and smaller amounts of quartzite. The sandstone gravels are severely weathered, friable, and have a brownish yellow color. The matrix is basically weathered to brownish red (Munsell 5YR4/6) clay, except that the weather-resistant fine quartz gravels are still well preserved (Fig. 3D).

Terrace T3 is mainly distributed in Yaan city, Duoying town, as well as in the piedmont zone to the west of Daxing town (Fig. 3A, profile 3). West of Daxing town, the strath of the Cretaceous brownish red sandstone is uncovered, and the alluvial gravel layer is $18.5 \pm 0.1 \mathrm{~m}$ thick. The tread and the strath are, respectively, $48.0 \pm 1.0$ and $29.5 \pm 1.0 \mathrm{~m}$ above the present river. An outcrop can be found that has a visible thickness of $9.4 \mathrm{~m}$. The matrix between the gravels is brown clayey (Munsell 5YR5/6) sand (Fig. 3D).

Terrace T2 is widely distributed on both sides of the Qingyijiang River in Yaan city. It lies on the west bank of the river near Duoying town upstream of Yaan (Fig.3A, profile 2). The terrace tread is $20.0 \pm 0.5 \mathrm{~m}$ above the present river. The visible alluvium of the mainstream is an 11-meter-thick gravel layer. The matrix is reddish brown (Munsell 7.5YR5/3) sand and silt (Fig. 3D).

Terrace T1 is mainly distributed along the downstream reach of Yaan city. It lies northwest of the Zengjiawu village on the north bank of the Qingyijiang River (Fig. 3A, profile 1). The terrace tread is $7.8 \pm 0.5 \mathrm{~m}$ above the present river, and the outcropped 5.0-m-thick alluvial layer on the top of the terrace exhibits a binary structure (from the bottom up): a 3.0-m-thick gravel layer with a loose gray (Munsell 7.5YR3/2) sand matrix and a 2.0-m-thick brown (Munsell 10YR4/3) silt layer on top (Fig. 3D). 


\section{Methodology}

\subsection{Field survey and measurement}

To guarantee that the measurements were of sufficiently high precision, a mobile GPS survey station with an $8 \mathrm{~cm}$ altitude precision was used in this research to conduct network RTK (real-time kinematic) measurements based on SCGNSS (Sichuan global navigation satellite system CORS), which was developed by the Sichuan Bureau of Surveying, Mapping and Geoinformation ${ }^{2}$.

To understand the precise landform of the alluvial fans and their connection with the Qingyi River, five topographic cross sections were measured in the fieldwork (B-B', C-C', D-D', E-E', and F-F' in Fig. 1B). Controlling points were set in a pivotal place to ensure the sections' accuracies, and the contact relation between the gravel and bedrock was surveyed intensively.

Moreover, to investigate the relation between the alluvial fan and modern terraces, longitudinal profiles of the MQF and DSF were established along the axis of projections I and II, respectively (Fig. 1B). Analogously, a longitudinal profile of the modern Qingyi River terraces was made along the axis of projection III (Fig. 1B).

\subsection{Sedimentary test}

From the field survey, we found that the matrix colors belonging to the different ranks vary from one another obviously. As a whole, the color of the matrix sand turns gradually darker with a more red-brown tone. Considering the humid regional climate, the variation in color is possibly influenced by weathering. However, without a marker bed, it is impossible to convincingly

\footnotetext{
2 SCGNSS is based on 60 continuously running satellite stations within Sichuan Province (the statistics are as of January 2015); in the system, plane precision is $5 \mathrm{~cm}$ and the ground elevation accuracy is $8 \mathrm{~cm}$.
} 
distinguish the different geomorphological surfaces.

Therefore, sedimentary samples belonging to each geomorphological surface were collected, including terraces T1 T6, MQF and DSF (the sample locations are in Fig. 1A). To avoid excessive erosion, samples were collected at a depth of $\sim 2 \mathrm{~m}$ beneath the surface based on the weathering degree of the morphological surface. In addition, samples were tested for bulk element composition and particle size to contrast the weathering degree and physical diversity. The bulk element and particle size testing was completed at the Key Laboratory of Crustal Dynamics, China Earthquake Administration.

\subsection{Chronology}

The age of the geomorphological surface studied in this article varied from thousands of years (T1, Tang et al., 2009) to the middle Pleistocene (Zhang et al., 1982, 2000). Therefore, multiple dating methods were applied to test the ages of the fan and terrace. Carbon isotope dating $\left({ }^{14} \mathrm{C}\right)$ is applied to terrace T1; optical stimulated luminescence dating (OSL) was applied to T2 and T3; and electron spin resonance dating (ESR) was used for terraces T4, T5, and T6, MQF, and DSF. The samples were collected from the outcrop at a depth of $\sim 2 \mathrm{~m}$ to attempt to approach the age of the morphological surface (Figs. 3C, 3D). Distribution of age samples are shown in the regional map (Fig. 1B).

The carbon isotope dating was finished at the School of Archaeology and Museology, Peking University. The OSL dating was finished at the Key Laboratory of Crustal Dynamics, China Earthquake Administration. The ESR dating was finished at the State Key Laboratory of Earthquake Dynamics, China Earthquake Administration. 


\section{Result}

\subsection{Measured cross sections}

According to the restored alluvial fan sector excluding the erosion effects of the modern rivers, we can see that the ancient alluvial fan sector is rather continuous on the whole; the alluvial fan diverges toward the northeastern direction from the fan apex next to Mingshan county, and the paleocurrent direction is clearly reflected (Fig. 2B). To more specifically study the morphology of the alluvial fan, and the contact relation between the ancient fans and modern Qingyi River, five topographic cross sections were established that focus on the height of morphological surface and the bedrock (Fig. 1B). In addition, the thickness of gravels was surveyed in detail to enable speculation on the paleo shape of the alluvial fans.

To understand MQF in detail, three topographic sections were measured: E-E', B-B', and C-C'. Seen from E-E', the overall morphology of the MQF is in good condition, and the thickness of its sediments is stable; notably, the alluvial fan on the western side is prominently lower (Fig. 4, E-E') and is close to the modern Qingyi River (Fig. 1B, E-E'). According to B-B', the alluvial fan area that is close to Longmen Shan on the northwest has been uplifted under the action of tectonism, which has generated a dip angle that leans to its axis (Fig. 4, B-B'). However, the influences of the tectonism become less obvious in the direction of the fan edge (Fig. 4, C-C'). In addition, the Dayi conglomerate (Neogene) that is near the submountain region on the NW side is generally $100 \mathrm{~m}$ higher than the MQF, which has the earliest river sedimentary record within the study area, although its range of distribution is limited.

For the DSF, two topographic cross sections were established: F-F' and D-D'. Based on the restored paleotopography (Fig. 2B) and section F-F' (Fig. 4, F-F'), although its peripheral part has 
been eroded, the earliest alluvial fan morphology is preserved on its western side, and the fan apex has the highest elevation relative to the entire DSF. Therefore, this area of the alluvial fan was denoted DSF1 (marked in Fig. 2B) to represent the early deposition of DSF. In line with D-D', the alluvial fan formed in the late stage was impacted by the tectonic uplift of the Sansuchang anticline (SSCA), which suffered the effects of a rather powerful erosion effect. In addition, the core of the anticline has been eroded into vallies; diluvium with a certain thickness has been preserved on the NW and SE sides of the core, which have not yet eroded. Distinct from the gravel layer of the DSF, the gravel at the top of the anticline is a sedimentary stratum formed after weathering erosion, has a sedimentary thickness $<5 \mathrm{~m}$, and is evenly distributed at the top of the anticline (pictures in Fig. 4). Filled with humus and clay between gravels, this stratum is very loose. The redeposit gravels are mainly comprised of weathered quartzite (Fig. 4) with larger grain sizes ranging from 10 to $20 \mathrm{~cm}$. Therefore, considering of the impacts of the SSCA, the area of the DSF is not only uplifted but also suffers from rather strong weathering denudation, and it was denoted DSF2 (marked in Fig. 2B) to represent the later period of the deposition of the DSF. In a word, the tectonic activity of the SSCA influenced the paleogeomorphology of the DSF, which is predicted to be distributed from west to east at the very beginning in this region.
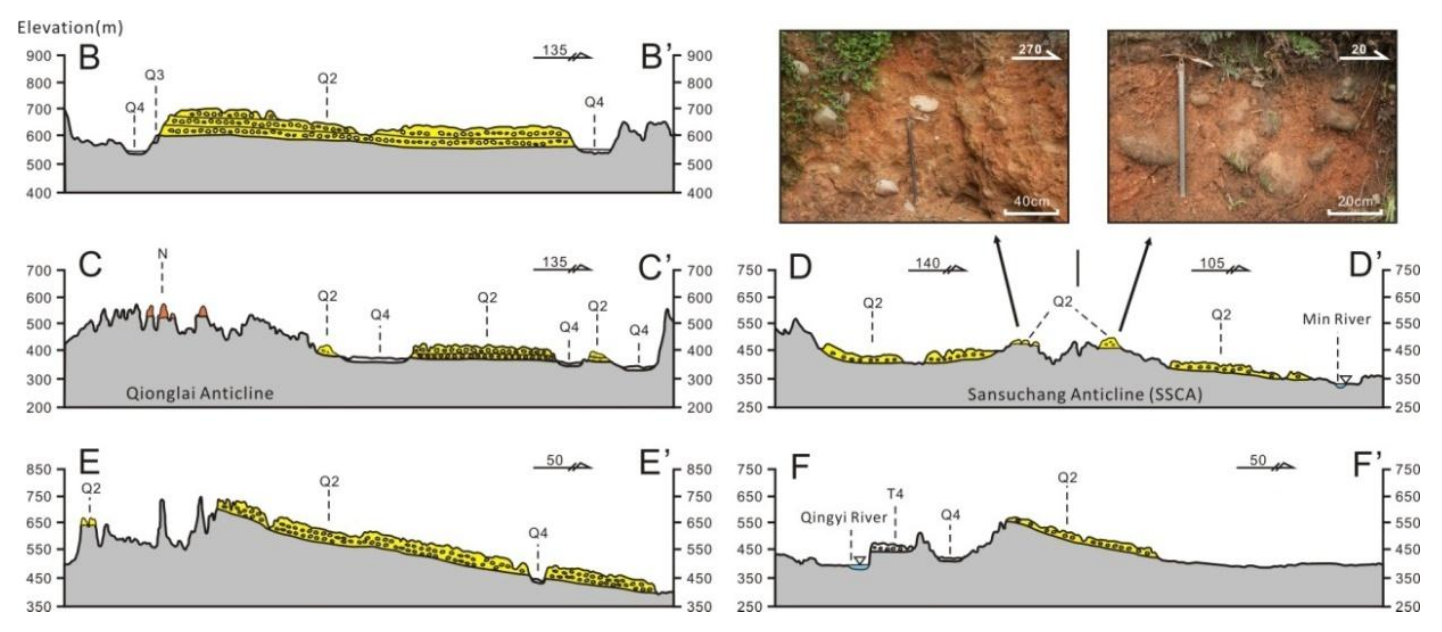
Fig. 4. Measured sections for the MQF and DSF. B-B' and C-C' are cross sections of the MQF, whereas E-E' is its longitudinal section; D-D' is the cross section of the DSF, whereas F-F' is its longitudinal section. The locations of the sections are shown in Fig. 1B. The picture shown in this figure refers to the residual pluvial gravel layer at the top of the SSCA.

\subsection{Relation between the alluvial fan and terrace}

The height of the paleogeomorphological surfaces above the modern riverbed may have been altered because of the actions of climate or structural activities, but the spatial height is continuous (Burbank et al., 2011; Huggett, 2007). In this study, the heights of the various geomorphological surfaces within the region were measured to distinguish their spatial heights and distributions. For the purpose of further comparisons, the field measurement results were projected on axes I, II, and III, which represent the flow directions of the Qingyi River in different periods (Fig. 1B). In detail, axis I represents the flow direction of the ancient Qingyi River during the sedimentary period of the MQF, and the highland and lowland were projected along the axis; axis II represents the flow direction of the ancient Qingyi River during the sedimentary period of the DSF, and DSF1 and DSF2 (defined in section 3.1) were projected along the axis; and axis III is the projection axis of the modern Qingyi River terrace. The starting points for the three projection axes are all in Yaan city, and their projection lengths are basically the same. When the projection drawings of axes I and III are overlain (Fig. 5A), the relationships of the heights of the MQF and the river terrace can be compared, and analogously the relation between the DSF and the river terrace can be compared by overlaying the axes II and III projection drawings (Fig. 5B). 


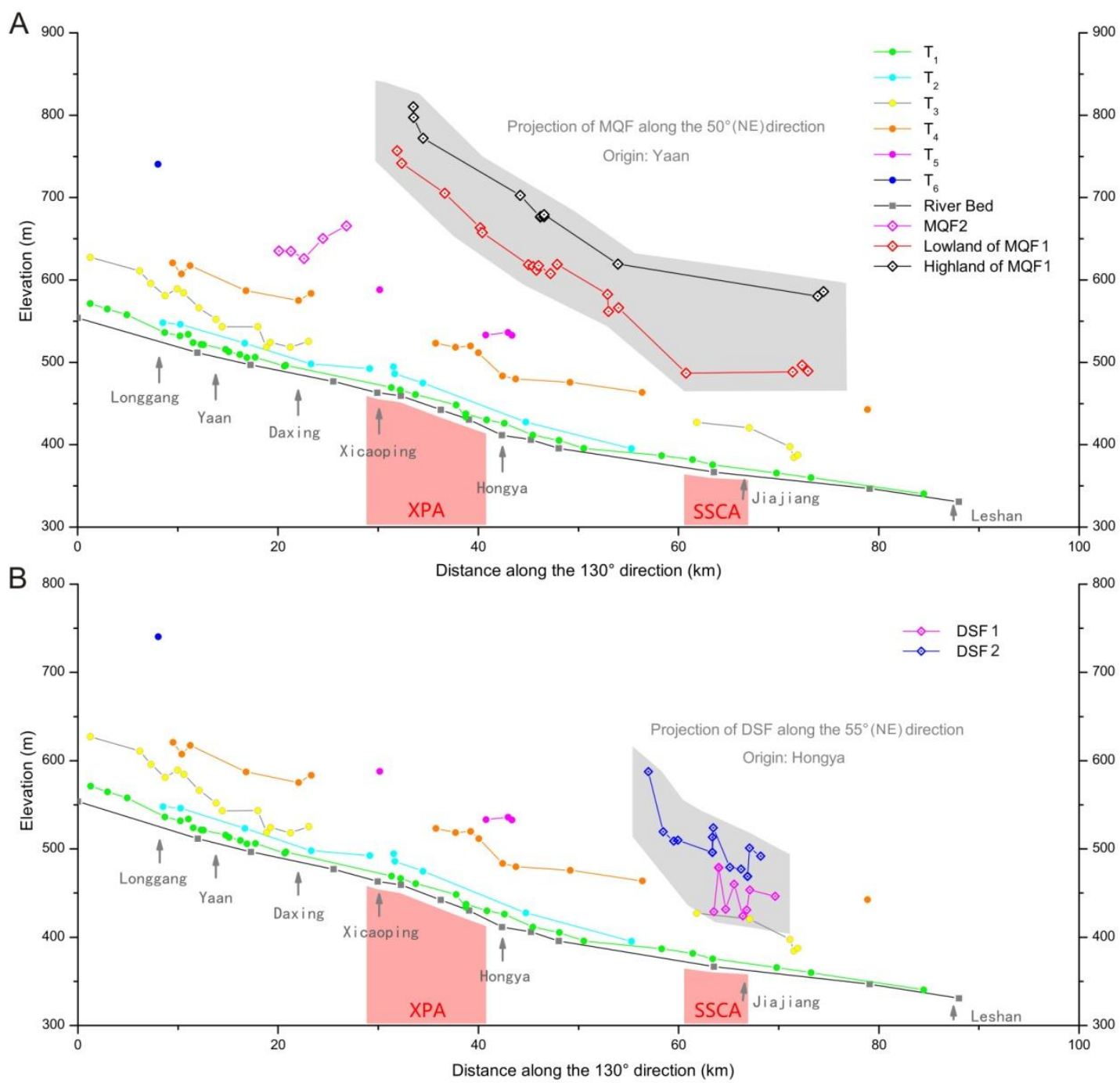

Fig. 5. Projection drawings of the alluvial fan and river terrace. (A) The overlay chart of projection axes I and III,

which was used to compare the MQF with the river terrace; (B) the overlay chart of projection axes II and III,

which was used to compare the DSF with the river terrace. The projection axes are marked in Fig. 1B. The

abbreviations are defined in the footnote on the first page.

Based on the overlaid projections of the MQF and the Qingyi River terrace (Fig. 5A), we can see that when the MQF extends toward the upper stream along projection axes I, T6 is much lower than the tendency of the alluvial fan's slope. Therefore, the formation time of the MQF was earlier than that of T6, and when T6 took shape, the MQF had already been abandoned. Seen from that figure, the slope of the ancient alluvial fan was larger than that of the modern Qingyi River. It 
illustrates that the regional fluvial function converted from accumulation during the MQF period to transportation in the modern period. In addition, a series of small ground platforms existed between the MQF and the modern Qingyi River (west of E-E' in Fig. 4), which shows a westward flow direction. Although the height conforms to T5, its trend is opposite to that of the MQF. The related reasons are predicted as follows. After the MQF has been abandoned, the tributaries in the region collected in the southwest instead of flowing toward the northeast and combined with the retrogressive erosion effect that caused part of the fan apex area to erode. In that process, the T5 terrace developed at the same time along the rechanneled Qingyi River. Therefore, we denote the main part of MQF as MQF1, and the opposite-trend platforms that developed in the later period are denoted MQF2 (marked in Fig. 5A).

According to the overlaying projection of the DSF and the Qingyi River terrace (Fig. 5B), the T6 terrace spatially corresponds to the higher alluvial fan sector of the DSF, and it should be the geomorphological surface at the same level as the early DSF. Terrace T5 corresponds to the lower alluvial fan sector of the DSF; however, because the low geomorphological surface has been severely deformed by the SSCA, this correspondence is not very definite. However, in line with the topographic feature survey of the modern Qingyi River, T5 is continuously developed along the river at Caoba town town, Xicaoping village, and Hongya county north of the SSCA, whereas it is not developed in the south. Thus, we can predict that at the time of the formation of T5, the Qingyi River did not yet run through the SSCA, and T5 should correspond to the lower geomorphological surface in the DSF.

\subsection{Chemical weathering distinction}

Previous researchers who have studied structural problems using river terraces have typically 
adopted spatial elevations or marker horizons to categorize terraces (Lavé et al., 2000; Pan et al., 2003). However, in this study's research area, where vegetation is flourishing and weathering is strong, finding a marker horizon is difficult and implementing large numbers of geomorphological surface age tests is unpractical. Under these circumstances, using other methods to convincingly categorize the morphological surfaces is important and necessary.

The weathering degree of the gravels reflects the condition of the sediments. In the high terraces and alluvial fans, the gravels are weathered and broken, but the gravels in the low terraces are basically unweathered. The sandstone and mudstones on the alluvial fans, for example, have been weathered into mud. Moreover, the provenance of those gravels is not uniform. Some of the gravels derive from distant source sediments on the upper reaches of the river, and others derive from proximal deposits from nearby tributaries. Consequently, making corresponding comparisons is difficult.

However, the matrixes that fill the spaces between the gravels are rather uniform. Because they have been transported over long distances, they have all been abundantly mixed. In the field survey, we found that the low geomorphological surfaces are enormously different from the high ones in profiles close to the surface. Specifically, as the degree of weathering increases, the matrix sands have been gradually changed into fine sands and clay from coarse sands; the color of the matrix also varies regularly (Figs. 2E, 3C, 3D). For example, the color of the matrix sand in T1 deposits is $7.5 \mathrm{YR} 3 / 2$, that of $\mathrm{T} 2$ is $7.5 \mathrm{YR} 5 / 3$, that of $\mathrm{T} 3$ is $5 \mathrm{YR} 5 / 6$, that of $\mathrm{T} 4$ is $5 \mathrm{YR} 4 / 6$, and that of T5 is $2.5 \mathrm{YR} 3 / 6$. Gradually, the brown tone increases as the terrace becomes older. Moreover, the matrix colors of $\mathrm{T} 6$ and the alluvial fans are similar.

Therefore, samples were collected from the terraces and alluvial fans to analyze their degree of 
weathering by major element and grain size tests. With these tests, we expected to verify whether geomorphological surfaces at the same level share weathering to the same degree and whether terraces and alluvial fans of different levels can be distinguished from one another. The sampling sites for the terraces and alluvial fans were at depths of $\sim 2 \mathrm{~m}$ from the surface; and if surface erosion is especially strong, the depths were greater. In addition, the matrix filling the intervals between the gravels were collected as test samples.

\subsubsection{Major element test}

To describe the mineral characteristics of river sediments (Nesbitt and Young, 1982), the major element test is technically fairly mature (Canfield, 1997; Vital et al., 2000). Past studies have emphasized the analysis of modern riverbed sediments and suspended matters to study the provenance of rivers (Singh et al., 2005; Liu et al., 2009; Singh, 2009), source region weathering (Johnsson et al., 1991), and regional tectonic evolution issues (Roddaz et al., 2006). Nevertheless, major element analyses have not yet been widely applied to study ancient river sediments.

In this paper, the representative matter contents are listed for comparison in addition to the major element analysis results (Table 1), including the content of upper continental crust (UCC), terrigenous shale (Taylor et al., 1985), world sediments (WS; McLennan, 1995), Luochuan loess (Chen et al., 1997), Xiashu loess (Li et al., 2007), western Sichuan laterite (Ying et al., 2012), and Xuancheng laterite (Li et al., 1999). Among those contents, UCC represents the original upper continental crust that has not been weathered, terrigenous shale is a typical product of upper crust weathering, WS is a comprehensive indicator for the statistics of various sediments all over the world, and the average weathering degree represented by WS lies between UCC and the terrigenous shale (Table 1). 
Table 1

Major element testing results

\begin{tabular}{|c|c|c|c|c|c|c|c|c|c|c|c|c|}
\hline Sample & Name & $\mathrm{SiO}_{2}$ & $\mathrm{Al}_{2} \mathrm{O}_{3}$ & $\mathrm{CaO}$ & $\mathrm{TFe}$ & $\mathrm{K}_{2} \mathrm{O}$ & $\mathrm{MgO}$ & $\mathrm{MnO}$ & $\mathrm{Na}_{2} \mathrm{O}$ & $\mathrm{P}_{2} \mathrm{O}_{5}$ & $\mathrm{TiO}_{2}$ & CIA \\
\hline 1 & $\mathrm{~T} 1$ & 63.0 & 6.8 & 4.9 & 10.8 & 4.6 & 3.2 & 0.2 & 4.4 & 0.4 & 1.7 & 25.9 \\
\hline 2 & $\mathrm{~T} 1$ & 65.3 & 7.3 & 2.0 & 12.0 & 4.9 & 3.1 & 0.1 & 2.5 & 0.5 & 2.0 & 35.7 \\
\hline 3 & $\mathrm{~T} 1$ & 65.3 & 10.1 & 2.3 & 8.1 & 4.1 & 2.5 & 0.1 & 3.4 & 0.3 & 1.1 & 41.8 \\
\hline 4 & $\mathrm{~T} 1$ & 67.4 & 10.0 & 2.2 & 6.6 & 4.4 & 2.2 & 0.1 & 3.8 & 0.3 & 0.9 & 40.0 \\
\hline 5 & $\mathrm{~T} 1$ & 64.2 & 10.3 & 3.3 & 8.7 & 3.9 & 2.5 & 0.1 & 3.6 & 0.3 & 1.4 & 38.9 \\
\hline 6 & $\mathrm{~T} 1$ & 61.7 & 10.1 & 4.3 & 9.0 & 3.5 & 3.2 & 0.1 & 3.7 & 0.3 & 1.4 & 38.9 \\
\hline 7 & $\mathrm{~T} 2$ & 65.4 & 7.2 & 3.7 & 11.2 & 4.3 & 2.6 & 0.1 & 4.2 & 0.3 & 1.0 & 28.4 \\
\hline 8 & $\mathrm{~T} 2$ & 68.3 & 9.3 & 2.3 & 7.9 & 3.6 & 2.3 & 0.1 & 4.5 & 0.5 & 1.2 & 37.7 \\
\hline 9 & $\mathrm{~T} 2$ & 63.9 & 9.6 & 3.0 & 13.5 & 2.4 & 2.2 & 0.1 & 2.4 & 0.4 & 2.1 & 47.5 \\
\hline 10 & $\mathrm{~T} 2$ & 64.4 & 10.3 & 3.0 & 8.5 & 4.0 & 2.3 & 0.1 & 3.6 & 0.3 & 1.2 & 39.8 \\
\hline 11 & $\mathrm{~T} 2$ & 62.0 & 10.8 & 3.4 & 8.6 & 4.4 & 2.5 & 0.2 & 4.4 & 0.3 & 1.1 & 37.3 \\
\hline 12 & $\mathrm{~T} 2$ & 65.1 & 10.3 & 3.0 & 7.7 & 4.1 & 2.4 & 0.1 & 3.7 & 0.3 & 1.1 & 39.2 \\
\hline 13 & $\mathrm{~T} 2$ & 63.6 & 11.0 & 2.9 & 9.0 & 3.8 & 2.3 & 0.1 & 3.4 & 0.3 & 1.2 & 42.3 \\
\hline 14 & $\mathrm{~T} 3$ & 60.8 & 11.7 & 2.7 & 13.7 & 3.7 & 2.0 & 0.1 & 3.4 & 0.4 & 1.3 & 44.5 \\
\hline 15 & $\mathrm{~T} 3$ & 59.9 & 11.8 & 2.9 & 14.2 & 2.6 & 2.7 & 0.3 & 2.2 & 0.4 & 2.7 & 54.3 \\
\hline 16 & $\mathrm{~T} 3$ & 57.7 & 12.6 & 2.9 & 11.1 & 3.3 & 2.4 & 0.2 & 2.9 & 0.2 & 1.5 & 49.3 \\
\hline 17 & $\mathrm{~T} 3$ & 56.4 & 12.8 & 2.2 & 12.8 & 3.1 & 2.4 & 0.2 & 2.1 & 0.2 & 1.6 & 55.8 \\
\hline 18 & $\mathrm{~T} 3$ & 54.4 & 13.2 & 2.9 & 13.0 & 3.0 & 2.5 & 0.2 & 2.5 & 0.2 & 1.6 & 53.5 \\
\hline 19 & $\mathrm{~T} 3$ & 58.0 & 12.8 & 2.1 & 11.0 & 3.7 & 2.2 & 0.2 & 2.5 & 0.2 & 1.4 & 51.8 \\
\hline 20 & $\mathrm{~T} 4$ & 75.3 & 12.5 & 0.3 & 6.9 & 2.4 & 1.0 & 0.0 & 0.3 & 0.1 & 1.1 & 78.1 \\
\hline 21 & $\mathrm{~T} 4$ & 63.5 & 14.7 & 1.1 & 11.2 & 3.7 & 2.2 & 0.4 & 0.9 & 0.1 & 1.7 & 67.8 \\
\hline 22 & $\mathrm{~T} 4$ & 68.5 & 13.0 & 0.4 & 6.2 & 3.3 & 1.3 & 0.0 & 0.4 & 0.1 & 1.1 & 73.0 \\
\hline 23 & $\mathrm{~T} 4$ & 72.0 & 11.9 & 0.2 & 5.5 & 2.7 & 1.0 & 0.0 & 0.3 & 0.1 & 1.0 & 76.8 \\
\hline 24 & $\mathrm{~T} 4$ & 75.0 & 9.6 & 0.4 & 6.1 & 2.2 & 1.1 & 0.0 & 0.5 & 0.1 & 1.1 & 71.0 \\
\hline 25 & DS & 72.6 & 12.1 & 0.2 & 10.3 & 1.9 & 0.6 & 0.1 & 0.3 & 0.1 & 1.7 & 80.5 \\
\hline 26 & DS & 57.8 & 14.1 & 0.2 & 14.6 & 2.1 & 0.9 & 0.0 & 0.3 & 0.1 & 1.7 & 81.6 \\
\hline 27 & DS & 58.8 & 15.6 & 0.4 & 11.6 & 2.2 & 1.0 & 0.0 & 0.3 & 0.1 & 1.7 & 82.3 \\
\hline 28 & DS & 60.9 & 14.7 & 0.2 & 16.9 & 1.7 & 0.8 & 0.0 & 0.2 & 0.1 & 2.4 & 86.1 \\
\hline 29 & MQ & 38.9 & 16.0 & 0.1 & 27.4 & 1.4 & 0.9 & 0.0 & 0.1 & 0.2 & 3.5 & 90.4 \\
\hline 30 & MQ & 49.2 & 14.1 & 0.1 & 21.5 & 1.8 & 0.8 & 0.0 & 0.1 & 0.2 & 2.8 & 86.1 \\
\hline 31 & MQ & 42.4 & 17.7 & 0.3 & 22.9 & 1.7 & 0.9 & 0.1 & 0.3 & 0.1 & 2.4 & 86.7 \\
\hline
\end{tabular}




\begin{tabular}{cccccccccccccccc} 
MQ & 47.5 & 17.7 & 0.2 & 18.4 & 1.9 & 0.9 & 0.1 & 0.2 & 0.1 & 2.8 & 86.8 \\
\hline UCC & 65.9 & 15.2 & 4.2 & 5.0 & 3.4 & 2.2 & 0.1 & 3.9 & 0.2 & 0.5 & 47.9 \\
World Sediments & 64.2 & 13.4 & 9.0 & 5.7 & 2.8 & 3.1 & 0.1 & 1.7 & 0.2 & 0.8 & 60.9 \\
Terrigenous Shale & 62.8 & 18.9 & 1.3 & 7.2 & 3.7 & 2.2 & 0.1 & 1.2 & 1.0 & 0.2 & 70.4 \\
Luochuan Loess & 66.4 & 14.2 & 1.0 & 4.8 & 3.0 & 2.3 & 0.1 & 1.7 & 0.2 & 0.7 & 64.4 \\
Xiashu Loess & 68.1 & 13.3 & 1.0 & 5.3 & 2.4 & 1.6 & 0.1 & 0.9 & 0.2 & 0.8 & 70.5 \\
Chuanxi Loess & 67.2 & 15.5 & 0.3 & 8.0 & 1.4 & 0.6 & 0.0 & 0.2 & 0.0 & 1.1 & 87.6 \\
Xuancheng Loess & 68.8 & 13.7 & 0.1 & 6.5 & 1.4 & 0.5 & 0.0 & 0.1 & 0.1 & 1.1 & 87.7 \\
\hline
\end{tabular}

In Table 1, the samples refer to the ancient geomorphological surfaces at all levels, and the numerical values of the major elements are expressed in percentage composition (\%); $\mathrm{TFe}_{2} \mathrm{O}_{3}$ is the total content of iron oxides, UCC is the content of upper crust materials (Taylor et al., 1985), WS is the material statistics of world sediments (McLennan, 1995); for Terrigenous shale (Taylor et al., 1985), Luochuan loess (Chen et al., 1997), Xiashu loess (Li et al., 2007), western Sichuan laterite (Ying et al., 2012), and Xuancheng laterite (Li et al., 1999), the average values of the original data are shown.

In accordance with element mobility, the overall weathering process can be divided into an early stage of draining of $\mathrm{Na}$ and $\mathrm{Ca}$, a middle stage of draining of $\mathrm{K}$, and a late stage of draining of $\mathrm{Si}$ (Nesbitt et al., 1980). In the view of preceding researchers, the loess has undergone a very strong weathering process; it tends to have completed the early stage (Chen et al., 1997) and has a sedimentary weathering level greater than the average without entering the middle stage of draining $\mathrm{K}$ in general. Laterite is principally distributed in the drainage basin of the Yangtze River in China, especially in its middle and lower streams, where a hot and humid environment has given rise to a rather powerful eluviation that has acted on laterite and produced a high weathering degree. At large, the laterite has already fulfilled the early stage, entered the middle stage, and even has a high degree of draining $\mathrm{K}$ ( $\mathrm{Li}$ et al., 1999). As a research object in this paper, the alluvial fan spans a time scale of $\sim 600 \mathrm{ka}$. On that basis, the two iconic sediments of loess and 
laterite were adopted to perform comparisons of the weathering periods at the early and middle stages, respectively. In addition, a corresponding analysis was also performed combined with a CIA-Na/K illustration, an A-CN-K triangle model diagram, as well as the Pettijohn and Herron lithology maturity classification figure.

\subsubsection{CIA-Na/K Illustration}

The Chemical Index of Alteration (CIA; Nesbitt et al., 1982), which serves as a geochemical index that can be used to judge the degree of chemical weathering, has been extensively applied (Johnsson et al., 1991; Singh et al., 2005; Caceres et al., 2013). As the host rock mineral in the crust, feldspar alters into clay minerals as the alkali metal runs off. Not only can CIA effectively indicate the extent that the feldspar in samples has been weathered into clay minerals, it can quantitatively reflect the degree of chemical weathering (Feng et al., 2003; Bahlburg et al., 2011), where

$$
\mathrm{CIA}=\left[\mathrm{Al}_{2} \mathrm{O}_{3} /\left(\mathrm{Al}_{2} \mathrm{O}_{3}+\mathrm{CaO}^{*}+\mathrm{K}_{2} \mathrm{O}+\mathrm{Na}_{2} \mathrm{O}\right)\right] \times 100
$$

In the equation, the contents of the oxides are represented by Moore molecules; $\mathrm{CaO}^{*}$ refers to the mole content in the silicate minerals, excluding the contents of $\mathrm{CaO}$ in carbonate and phosphate (Nesbitt et al., 1989, 1996).

Because $\mathrm{CaO}$ and $\mathrm{Na}_{2} \mathrm{O}$ usually occupy the same percentage in silicate, the computational method for $\mathrm{CaO}^{*}$ can be described as follows. In the case that the mole number of $\mathrm{CaO}$ is smaller than that of $\mathrm{Na}_{2} \mathrm{O}, \mathrm{m}(\mathrm{CaO})$ is the value of $\mathrm{m}\left(\mathrm{CaO}^{*}\right)$, and if the number is larger than that of $\mathrm{Na}_{2} \mathrm{O}, \mathrm{m}\left(\mathrm{CaO}^{*}\right)=\mathrm{m}\left(\mathrm{Na}_{2} \mathrm{O}\right)$ (McLennan, 1993); this correction approach is adopted in this paper.

The empirical results show that the CIA value for the unweathered feldspar is 50 and is 75 and 85, respectively, for illite and montmorillonite. For kaolin and chlorite, CIA nearly reaches 100. 
The stronger the chemical weathering, the larger the CIA value will be. Generally speaking, CIA values between 50 and 65 refer to moderate weathering in cold and dry climates. When CIA ranges from 65 to 85 , medium weathering under warm and humid weather is indicated, and strong weathering in hot and wet climates is represented by CIA values between 85 and 100 (Nesbitt et al., 1982).

The $\mathrm{Na} / \mathrm{K}$ ratio is an indicator of the degree of anorthose weathering in samples. Unlike anorthose (which is rich in $\mathrm{Na}$ ), potassium feldspar, illite, and mica are enriched in $\mathrm{K}$. Because the weathering rate of anorthose is far greater than that of potassium feldspar, the $\mathrm{Na} / \mathrm{K}$ ratio in the weathering profile is inversely associated with its degree of weathering (Nesbitt et al., 1989). By combining the CIA values and the $\mathrm{Na} / \mathrm{K}$ ratio data, a comprehensive weathering illustration was built (Fig. 6).

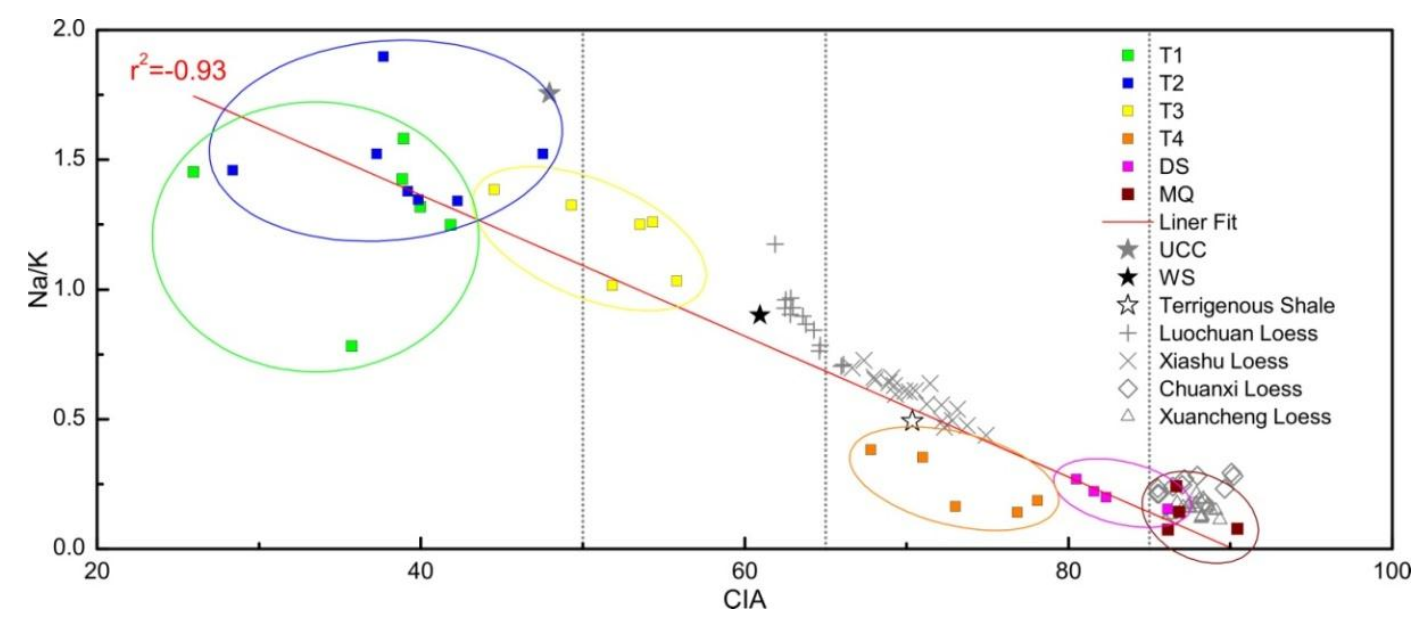

Fig. 6. CIA-Na/K weathering illustration. A fitting coefficient for the alluvial fan and terrace samples, $\mathrm{r}^{2}$ is projected onto the coordinate system with UCC and terrigenous shale (Taylor et al., 1985), WS (McLennan, 1995), Luochuan loess (Chen et al., 1997), Xiayu loess (Li et al., 2007), Xucheng laterite (Li et al., 1999), and Western Sichuan laterite (Ying et al., 2012).

We can see that an obvious negative correlation exists between $\mathrm{Na} / \mathrm{K}$ and CIA, which reflects 
the tendency that the degree of weathering of river sediments increases with age. From T1, T2, T3, T4, DSF to MQF, the degree of weathering gradually increases, and they can generally be separated from one another. The low terraces, including $\mathrm{T} 1$ and $\mathrm{T} 2$, are dispersed, and the geomorphological surfaces above T3 are weathered as a group (Fig. 6). Based on the figure, although the degree of weathering for the MQF is higher than that of the DSF, the difference is not as obvious as that for the low terraces. This phenomenon indicates that if river sediments of different ages are distinguished by their CIA values, the differences among the older sediments are not as great as that of the younger sediments. At the age of T4, the degree of weathering reached the same level as that of the terrigenous shale, although it was overall weaker than that for laterite (Fig. 6). Moreover, the obtained correlation coefficient for all of the samples from the Qingyi River was -0.93 .

\subsubsection{Triangle model diagram}

A-CN-K (Nesbitt et al., 1984) and A-CNK-FM triangle model illustrations (Nesbitt et al., 1989) are presented as representative of the weathering tendencies of the continental crust materials. The weathering of anorthose in the early stage of continental weathering corresponds to a tendency in parallel with the line from A to $\mathrm{CN}$ and points to A. At that stage, the typical weathering process is the tendency from the upper crust UCC to the terrigenous shale. In addition, because the river solutes represent soluble constituents during continental weathering, their composition point falls on the oppositely elongated line of the trend line. When the weathering trend point reaches the A-K connecting line, all of the anorthose in the weathering profile has been eliminated, and the weathering has entered the middle stage, which is marked by the weathering of potassium feldspar and illite. Furthermore, the relevant weathering tendency is in parallel with the A-K line. At the 
late stage of continental weathering, the constituents of the weathering products fall on places near point A and go through the Si-running-off process (Nesbitt et al., 1984).

The data for the terraces and alluvial fans used in this paper are projected into the triangle model diagram to compare the differences among geomorphological surfaces at all levels (Figs.

7A, 7B).
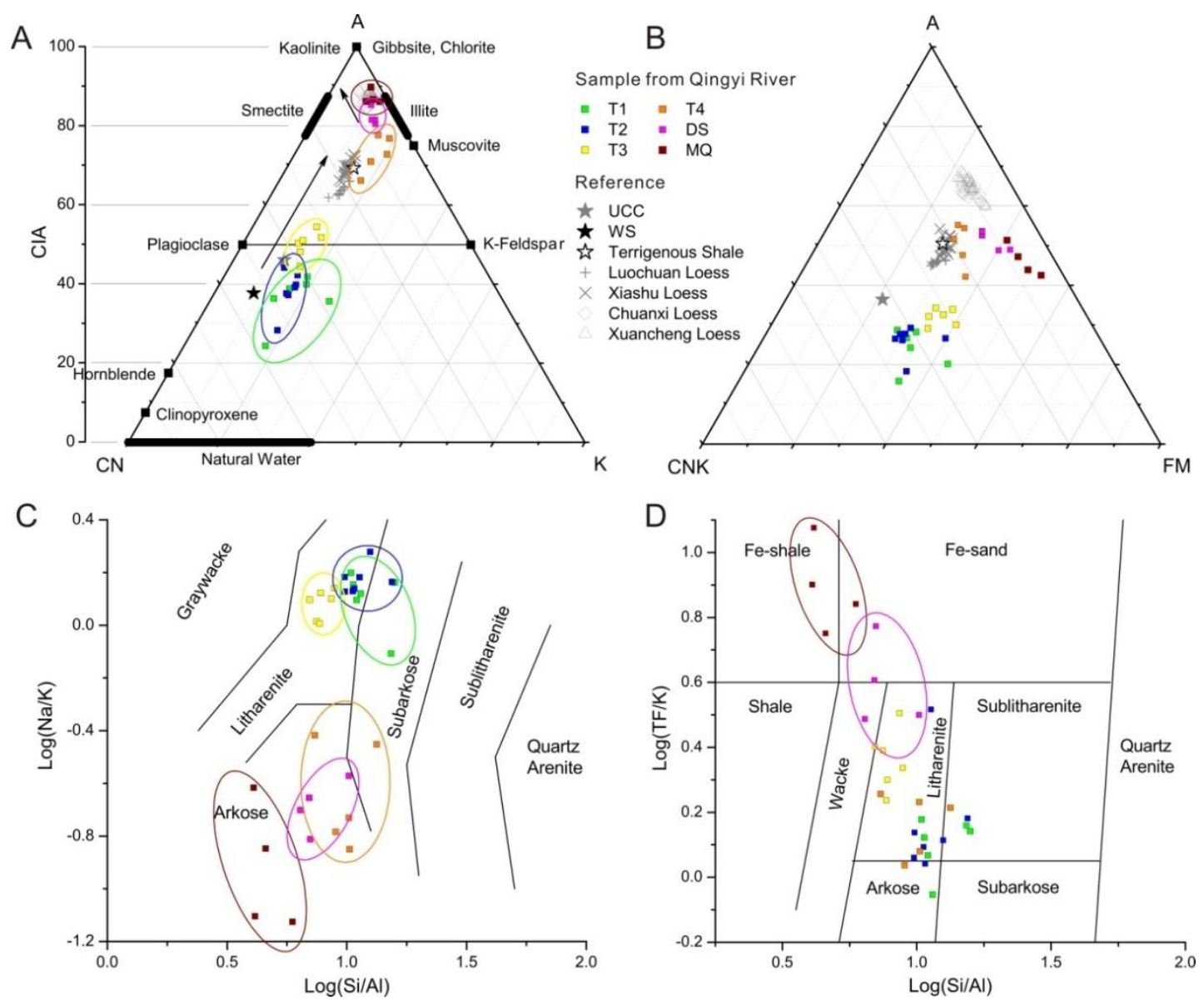

Fig. 7. Triangle main graph and classification map. In (A) and (B), $\mathrm{A}=\mathrm{Al}_{2} \mathrm{O}_{3}, \mathrm{CN}=\mathrm{CaO}+\mathrm{Na}_{2} \mathrm{O}, \mathrm{K}=\mathrm{K}_{2} \mathrm{O}, \mathrm{CNK}$

$=\mathrm{CaO}+\mathrm{Na}_{2} \mathrm{O}+\mathrm{K}_{2} \mathrm{O}$, and $\mathrm{FM}=\mathrm{Fe}_{2} \mathrm{O}_{3}+\mathrm{MgO} ;(\mathrm{C})$ the Pettijohn lithology classification (Pettijohn et al., 1973);

(D) the Herron lithology classification (Herron, 1988). The reference symbols are the same as those in Fig. 6.

In the A-CN-K triangle model (Fig. 7A), the weathering of loess conforms with the early weathering trend line from $\mathrm{CN}$ to A-K; for laterite which also goes through this process, it gradually develops toward the A-CN axis and finally is close to point A. The positions of $\mathrm{T} 1, \mathrm{~T} 2$, 
T3, T4, MQF, and DSF shown in the figure reflect that the Qingyi River sediments of different ages are significantly different; the weathering of $\mathrm{T} 1$ and $\mathrm{T} 2$, which is opposite that of UCC in direction, tends to follow the direction of natural water. The weathering tendencies of $\mathrm{T} 3$, T4, and the alluvial platform conform to the UCC weathering direction. The weathering tendency of the sediments, which increases as the ages of the sediments increase, is prominent and also exhibits obvious separation. The MQF and DSF sediments begin to develop toward the A-CN axis, which indicates that they have entered the middle stage of weathering.

Regarding the A-CNK-FM triangle model diagram (Fig. 7B), unlike UCC, the terrigenous shale, loess, and laterite, the sediments of the Qingyi River deviate to the FM angle on the whole. The diagram shows that the sediments are rich in $\mathrm{Fe}$ and $\mathrm{Mg}$ oxides, which benefits from fine-grain minerals such as the hydroxide of Fe and biotite that can be easily brought up by running water and suspended in river sediments in the process of river development, which is similar to characteristics of modern riverbed sediments (Vital et al., 2000; Singh et al., 2005). According to the analysis of the Qingyi River sediments presented in this paper (Fig. 7B), we can see that the separation characteristics projected by the geomorphological surfaces at all levels are very prominent, and this trend is identical with the weathering of UCC to terrigenous shale as well as the weathering tendencies of the loess and laterite.

\subsubsection{Lithology maturity classification}

The chemical index of the major elements such as $\mathrm{SiO}_{2} / \mathrm{Al}_{2} \mathrm{O}_{3}$ can be used to reflect the abundances of quartz, feldspars and clay minerals (Potter, 1978) as well as $\mathrm{Fe}_{2} \mathrm{O}_{3} / \mathrm{Al}_{2} \mathrm{O}_{3}$, which can reflect mineral stability and also be used to classify arkose (Herron, 1988). At the same time, comprehensive indicators are also able to reflect the maturity of sediments (Pettijohn et al., 1973). 
The sediments in the Qingyi River were projected into the Pettijohn and Herron lithology classification tables (Figs. 7C, 7D). We can see from the former figure (Fig. 7C) that the element properties of the Qingyi River sediments change from arkose and subarkose to litharenite as the samples increase in age. Meanwhile, from the latter figure (Fig. 7D), the element combination characteristics of the sediments vary from arkose, subarkose, and litharenite into Fe-sand and Fe-shale. Moreover, in the two classification figures, the geomorphological surfaces of the different levels show obvious separation characteristics: the older the sediment is, the higher maturity it holds.

\subsection{Grain size analysis}

As a basic sedimentological method, grain size analysis has been extensively applied (Bagnold et al., 1980; Davis, 1983). During the weathering of sands into soil, the grain size is gradually graded and becomes finer (Oldfield et al., 1985; Miller et al., 1987). In this study, grain size testing of the geomorphological surface samples for all levels was undertaken (Table 2).

Table 2

Grain size data. ${ }^{\mathrm{a}}$

\begin{tabular}{ccccccccccc}
\hline Sample & Name & $\varphi_{1}$ & $\varphi_{5}$ & $\varphi_{16}$ & $\varphi_{24}$ & $\varphi_{50}$ & $\varphi_{75}$ & $\varphi_{84}$ & $\varphi_{95}$ & $\varphi_{99}$ \\
\hline 1 & $\mathrm{~T} 1$ & 1.75 & 26.31 & 500.45 & 643.64 & 958.37 & 1315.1 & 1483.05 & 1857.29 & 2265.85 \\
2 & $\mathrm{~T} 1$ & 0.22 & 1.03 & 4.28 & 10.32 & 214.13 & 597.79 & 728.55 & 962.94 & 1164.75 \\
3 & $\mathrm{~T} 1$ & 0.31 & 1.45 & 6.91 & 21.99 & 218.75 & 458.27 & 566.86 & 787.04 & 978.18 \\
4 & $\mathrm{~T} 1$ & 0.71 & 3.49 & 77.59 & 251.87 & 519.34 & 772.54 & 888.83 & 1095.43 & 1195.09 \\
5 & $\mathrm{~T} 1$ & 2.91 & 268.74 & 675.02 & 828.7 & 1172.34 & 1568.33 & 1756.1 & 2232.32 & 2716.45 \\
6 & $\mathrm{~T} 1$ & 0.89 & 4.73 & 104.29 & 330.47 & 598.61 & 818.84 & 923.29 & 1136.96 & 1352.21 \\
\hline 7 & $\mathrm{~T} 2$ & 0.79 & 3.21 & 17.48 & 144.07 & 545.5 & 768.52 & 867.12 & 1086.32 & 1217.22 \\
8 & $\mathrm{~T} 2$ & 0.55 & 2.89 & 26.92 & 206.59 & 653.45 & 927.27 & 1044.13 & 1273.21 & 1422.64 \\
9 & $\mathrm{~T} 2$ & 0.29 & 1.29 & 4.23 & 7.47 & 29.04 & 99.33 & 133.54 & 208.43 & 296.21
\end{tabular}




\begin{tabular}{|c|c|c|c|c|c|c|c|c|c|c|}
\hline 10 & $\mathrm{~T} 2$ & 0.53 & 2.59 & 17.54 & 159.07 & 385.76 & 558.89 & 639.52 & 796.85 & 951.67 \\
\hline 11 & $\mathrm{~T} 2$ & 0.77 & 3.17 & 42.79 & 221.17 & 429.01 & 609.97 & 696.5 & 859.22 & 1052.5 \\
\hline 12 & $\mathrm{~T} 2$ & 0.9 & 3.55 & 43.03 & 245.01 & 439.08 & 609.68 & 695.14 & 865.07 & 1006.41 \\
\hline 13 & $\mathrm{~T} 2$ & 0.57 & 3.18 & 34.14 & 211.61 & 411.75 & 592.67 & 683.66 & 854.32 & 1052.14 \\
\hline 14 & $\mathrm{~T} 3$ & 0.22 & 0.97 & 4.31 & 11.99 & 272.6 & 646.6 & 772.46 & 1007.88 & 1199.77 \\
\hline 15 & $\mathrm{~T} 3$ & 0.18 & 0.66 & 2.6 & 6.37 & 148.3 & 613.24 & 742.83 & 987.42 & 1189.52 \\
\hline 16 & $\mathrm{~T} 3$ & 0.15 & 0.44 & 1.6 & 2.91 & 9.64 & 34.7 & 81.93 & 273.75 & 414.28 \\
\hline 17 & $\mathrm{~T} 3$ & 0.17 & 0.58 & 1.93 & 3.67 & 13.71 & 94.63 & 204.05 & 442.81 & 620.49 \\
\hline 18 & $\mathrm{~T} 3$ & 0.16 & 0.46 & 1.46 & 2.5 & 9.19 & 50.91 & 152.83 & 474.94 & 707.35 \\
\hline 19 & $\mathrm{~T} 3$ & 0.17 & 0.59 & 1.93 & 3.57 & 15.14 & 253.62 & 533.98 & 842.69 & 1110.18 \\
\hline 20 & $\mathrm{~T} 4$ & 0.17 & 0.59 & 1.64 & 2.74 & 11.04 & 65.26 & 105.32 & 173.37 & 242.29 \\
\hline 21 & $\mathrm{~T} 4$ & 0.17 & 0.51 & 1.32 & 2.02 & 5.68 & 16.58 & 26.42 & 61.65 & 131.36 \\
\hline 22 & $\mathrm{~T} 4$ & 0.18 & 0.66 & 1.76 & 2.98 & 16.31 & 81.48 & 103.01 & 144.92 & 193.96 \\
\hline 23 & $\mathrm{~T} 4$ & 0.16 & 0.53 & 1.53 & 2.54 & 10.14 & 62.8 & 91.59 & 153.23 & 226.08 \\
\hline 24 & DS & 0.12 & 0.22 & 0.75 & 1.29 & 3.87 & 11.35 & 17.65 & 40.26 & 105.12 \\
\hline 25 & DS & 0.11 & 0.16 & 0.33 & 0.55 & 1.33 & 2.79 & 4.73 & 14.91 & 25.11 \\
\hline 26 & DS & 0.12 & 0.21 & 0.71 & 1.29 & 4.05 & 12.36 & 19.55 & 45.63 & 119.86 \\
\hline 27 & MQ & 0.12 & 0.22 & 0.65 & 1.05 & 2.47 & 6.54 & 9.99 & 23.77 & 115.54 \\
\hline 28 & MQ & 0.12 & 0.2 & 0.56 & 0.97 & 2.39 & 10.89 & 19.32 & 41.54 & 113.75 \\
\hline 29 & MQ & 0.13 & 0.25 & 0.81 & 1.32 & 3.51 & 9.2 & 14.38 & 39.63 & 104.87 \\
\hline
\end{tabular}

${ }^{a} \varphi_{n}$ means that $\mathrm{n} \%$ of the grains in the samples have grain sizes greater than that value (unit: $\left.\mu \mathrm{m}\right)$.

The main grain size parameters of the samples were arranged according to the level of the geomorphological surface (Fig. 8). Among those parameters, the mean grain size (Mz) expresses the central tendency of the grain size distribution and reflects the mean kinetic energy of transport, the sorting coefficient $\left(\sigma_{1}\right)$ refers to the tendency of the grain size concentration and dispersion, skewness $\left(\mathrm{SK}_{1}\right)$ is used to judge the degree of asymmetry of the grain size distribution (Folk, 1966), and kurtosis $\left(\mathrm{K}_{\mathrm{G}}\right)$ can be employed to assess the steepness of the grain size frequency curve (Folk, 1966). Sahu granularity discriminant analysis serves as a multivariate statistical analysis approach that has been adopted to judge the sedimentary environments of particles (Sahu, 1964). 


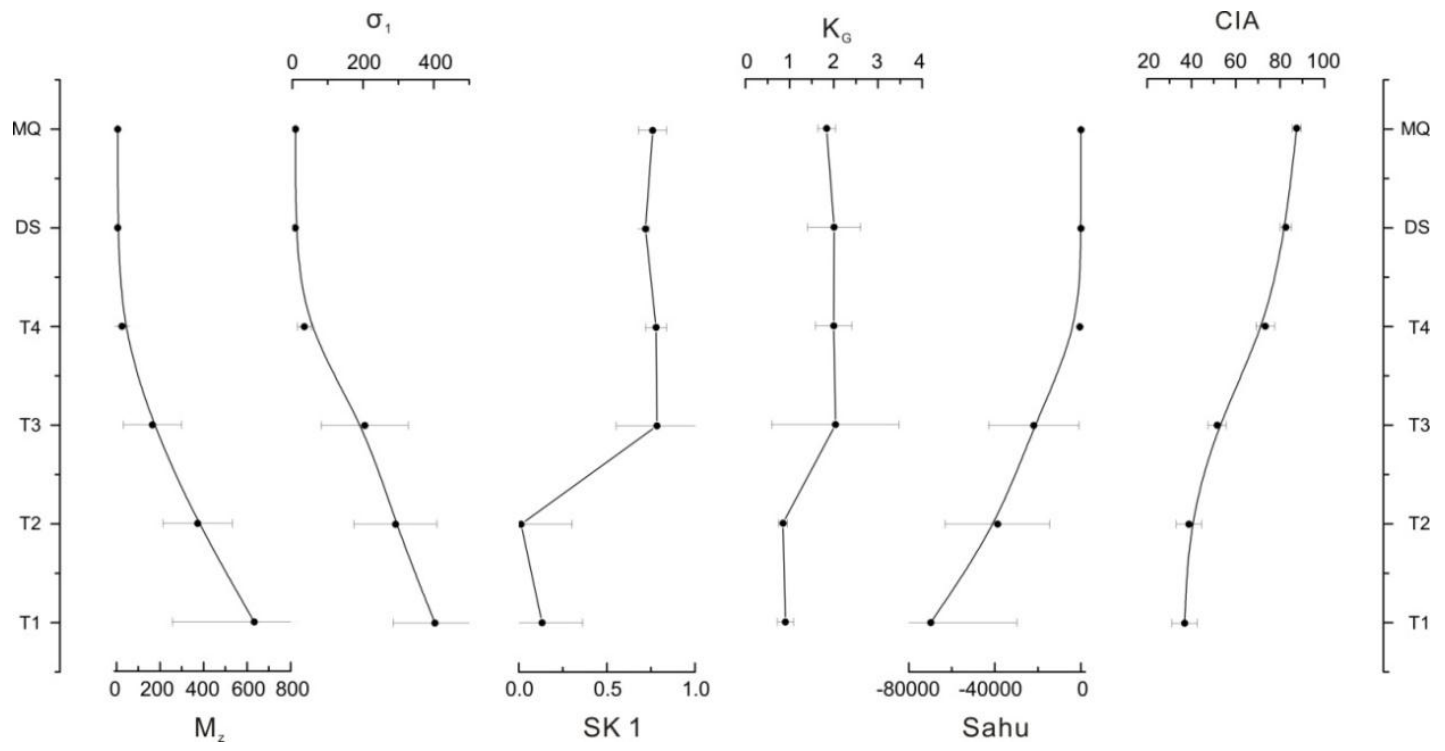

Fig. 8. Grain size parameter comparisons among the geomorphological surface samples. The parameter values are the mean values of all the geomorphological surface data. The error bar represents the standard deviation.

Clearly, the vast majority of the grain size parameters (including $\mathrm{Mz}, \sigma_{1}, \mathrm{~K}_{\mathrm{G}}$ and Sahu) vary regularly from the new geomorphological surfaces to the old (Fig. 8). Like the CIA weathering indicator, the grain size parameter not only reflects differences in geomorphological surface weathering but also indicates that the grain size is under the prominent control of weathering in strong weathering regions where river sediments are close to the upper sediment substrates. Furthermore, this parameter also reflects the relationship between the new and old sediments to a certain extent.

\subsection{Ages of the geomorphological surfaces}

Multiple dating methods were adopted in this study to test the ages of all of the geomorphological surfaces including ${ }^{14} \mathrm{C}$, OSL, and ESR (Table 3). Details of sample colltection and dating are dicussed in section 3.3. Note that $\mathrm{T} 3$ and $\mathrm{T} 5$ failed during the tests and that the age of T3 was referred to that in a preceding study (Tang et al., 2009). 
Meanwhile, the colors of the matrixes in the outcrop of all morphological surfaces were examined. The T1 matrix has a Munsell color of 7.5YR3/2, which is charcoal grey. The Munsell color of the T2 matrix is $7.5 \mathrm{YR} 5 / 3$, which is brown grey. The color of the T3 matrix is $5 \mathrm{YR} 5 / 6$, which is brown. The color of the T4 matrix is 5YR4/6, which is reddish brown. The color of the T5 matrix is $2.5 \mathrm{YR} 3 / 6$, which is reddish brown. The color of the T6 matrix is $2.5 \mathrm{YR} 4 / 6$, which is reddish orange. The color of the DSF matrix is $2.5 \mathrm{YR} 4 / 6$, which is reddish orange. The color of the MQF matrix is $2.5 \mathrm{YR} 4 / 8$, which is reddish orange (Table 3). We can see that the colors of the matrixes from new to old gradually become darker from the original brownish red, and generally the color transitions to brownish red from the gray tone. The colors of the profile sediment matrix can provide support for field surveys.

Table 3

Ages and sedimentary features of all the geomorphologic surfaces

\begin{tabular}{ccccccccc}
\hline Geomorphologic surfaces & T1 & T2 & T3 & T4 & T5 & T6 & DSF & MQF \\
\hline Test methods & ${ }^{14} \mathrm{C}$ & OSL & OSL & ESR & $/$ & ESR & ESR & ESR \\
Sampling sites & Yaan & Yaan & Yaan & Yaan & $/$ & Yaan & Danling & Mingshan \\
\hline & & & & & & & & $537 \pm 64$ \\
Ages (ka) & $5.9 \pm 0.025$ & $40.4 \pm 4.98$ & $93 \pm 10^{\mathrm{a}}$ & $185 \pm 19$ & $/$ & $300 \pm 60$ & $305 \pm 49$ & $421 \pm 42$ \\
& & & & & & & $268 \pm 54$ & $308 \pm 34$ \\
\hline Color & 7.5 YR3/2 & 7.5 YR5/3 & 5 YYR5/6 & 5 YR4/6 & 2.5 YR3/6 & 2.5 YR4/6 & 2.5 YR4/6 & 2.5 YR4/8 \\
CIA $^{\mathrm{c}}$ & 34.6 & 37.9 & 55.9 & 72.9 & 80.5 & $/$ & 83.3 & 86.1 \\
\hline
\end{tabular}

a The age of T3 has been given by preceding researchers (Tang et al., 2009).

${ }^{\mathrm{b}}$ Color refers to the color of the matrix between the gravels in a novel profile, and the Munsell soil color was adopted.

${ }^{\mathrm{c}}$ CIA is the mean value of the river terraces or alluvial fans. 


\section{Discussion and conclusions}

\subsection{Discussion}

\subsubsection{Geomorphological surface sequence}

By analyzing the sedimentary characteristics of multiple morphological surfaces, the classification of the terraces and fans is clear. Meanwhile, measurements of cross sections and longitudinal profiles are more convincingly applied to contrast different morphological surfaces. Comprehensively speaking, the formation process of the geomorphological surfaces from ancient to recent were determined (Fig .9): MQF1 $\rightarrow$ Qingyi River T6 / DSF1 $\rightarrow$ Qingyi River T5 / DSF2 / $\mathrm{MQF} 2 \rightarrow$ Qingyi River $\mathrm{T} 4 \rightarrow \mathrm{T} 3 \rightarrow \mathrm{T} 2 \rightarrow \mathrm{T} 1$. In addition, we can also predict that after the formation of the MQF and before the formation of T6, the Qingyi River begins to run through the XPA, and the MQF was therefore abandoned. Subsequently, when T6 developed along the Qingyi River, DSF1 developed downstream. After the formation of T5 / DSF2 and prior to the formation of T4, the river ran through the SSCA, and DSF1 and DSF2 were therefore abandoned. 


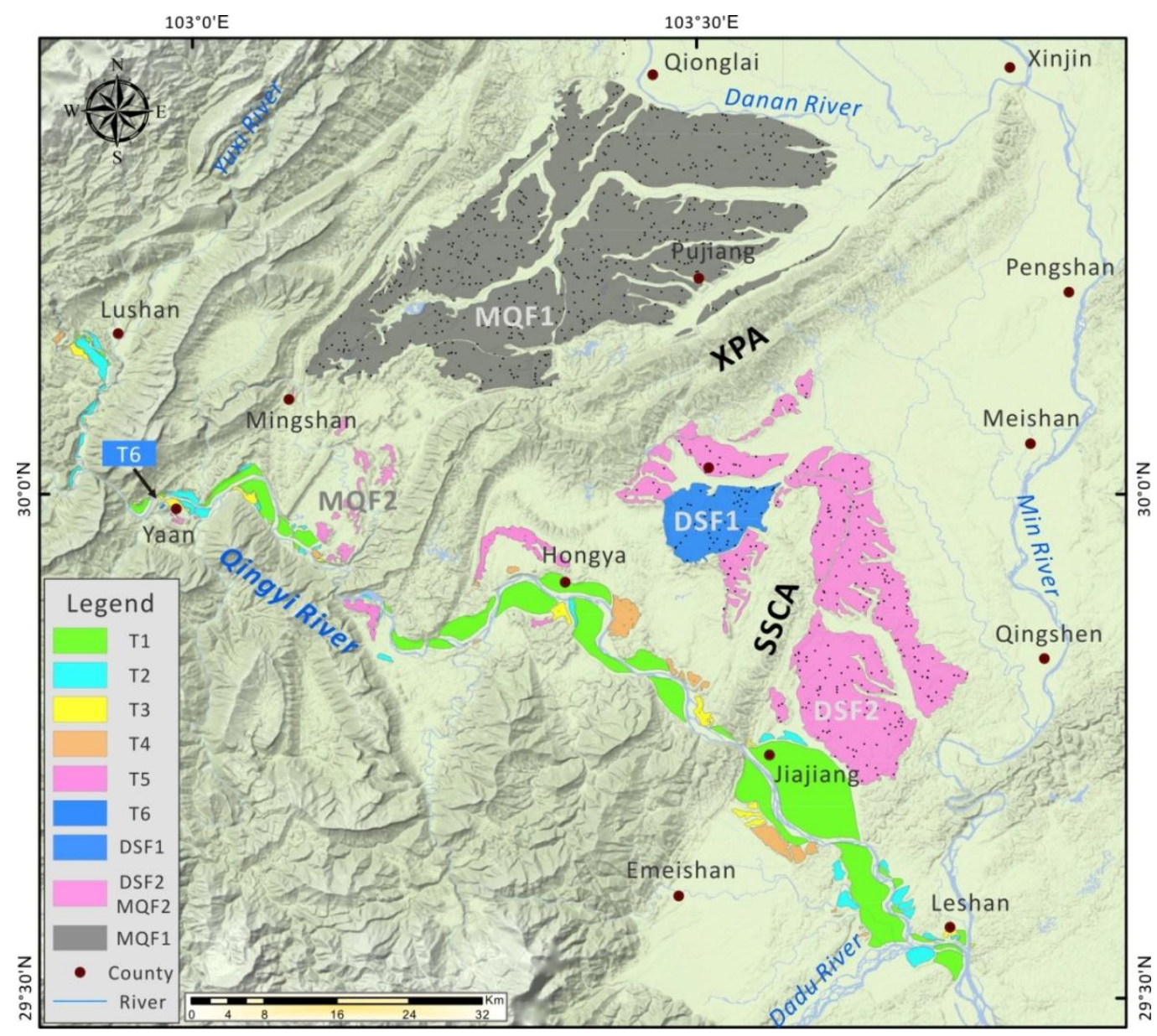

Fig. 9. Geomorphological surface sequence distribution in the research area. Sites with the same color in the river terraces and alluvial fans represent the geomorphological surfaces at the same period, and they are spatially continuous. The abbreviations are defined in the footnote on the first page.

\subsubsection{River evolution history}

Based on the measurements and analyses discussed above, the history of river evolution was determined, and the history was divided into four primary periods. Moreover, the geomorphological surfaces at different elevations developed in different periods, and they are distributed at various locations in the foreland region. The evolution of the river and the geomorphological surface development in different periods were impacted by the tectonic activity from the XPA or SSCA. The primary evolutionary histories of the four periods are as follows. 
(1) MQF1 period (537 308 ka). During the early-to-mid period of the middle Pleistocene, the MQF developed between Longmen Shan and the XPA, and its complete sedimentary geomorphological surfaces have been well preserved and reflect the slopes of the alluvial fan at that time. However, for the modern Qingyi River, no geomorphological surface records exist from that period; therefore, the mountain outlet of the ancient Qingyi River clearly should have been in the area of Mingshan at that time, and the river had not yet run through the XPA. The fan apex zone eroded in the late period (Fig. 10A).

(2) DSF1 period (305 $268 \mathrm{ka}$ ). During the middle period of the middle Pleistocene, as the erosion toward the riverhead on the south of the XPA cut through the southwestern part of the anticline, the Qingyi River was captured into the stream and thus ran through the XPA. Consequently, the MQF was gradually abandoned. When the deposition of DSF1 began, the corresponding T6 terrace was formed in the Qingyi River in the same period (Fig. 10B).

(3) DSF2 period (268 $185 \mathrm{ka}$ ). During the late period of the middle Pleistocene, the large-scale alluvial fan began to take shape in the Danling-Simeng area, and the SSCA began to be uplifted at the same time. In addition, the morphology of DSF2 was transformed in a synsedimentary process. During the period, the abandoned tributary on the western side of the MQF and the local piedmont tributary began to merge into the current Qingyi River and formed a series of local alluvial fans, MQF2, which were in the opposite direction of the MQF1 slope. At the same time, the T5 terrace, which had not yet formed on the south side of the SSCA, developed along the modern Qingyi River. This phenomenon indicates that the SSCA was not cut by the Qingyi River in this period (Fig. 10C).

(4) T4 T1 period (185 ka now). During the period from the late middle Pleistocene to the 
present, after the SSCA had been completely uplifted, it cut off the extension of DSF2; in the meanwhile, as the headward erosion by the tributary on the southern foot of the SSCA occurred, the modern Qingyi River course that cuts through the SSCA was formed. Afterward, the T4, T3, T2, and T1 terraces developed on both sides of the Qingyi River (Fig. 10D).
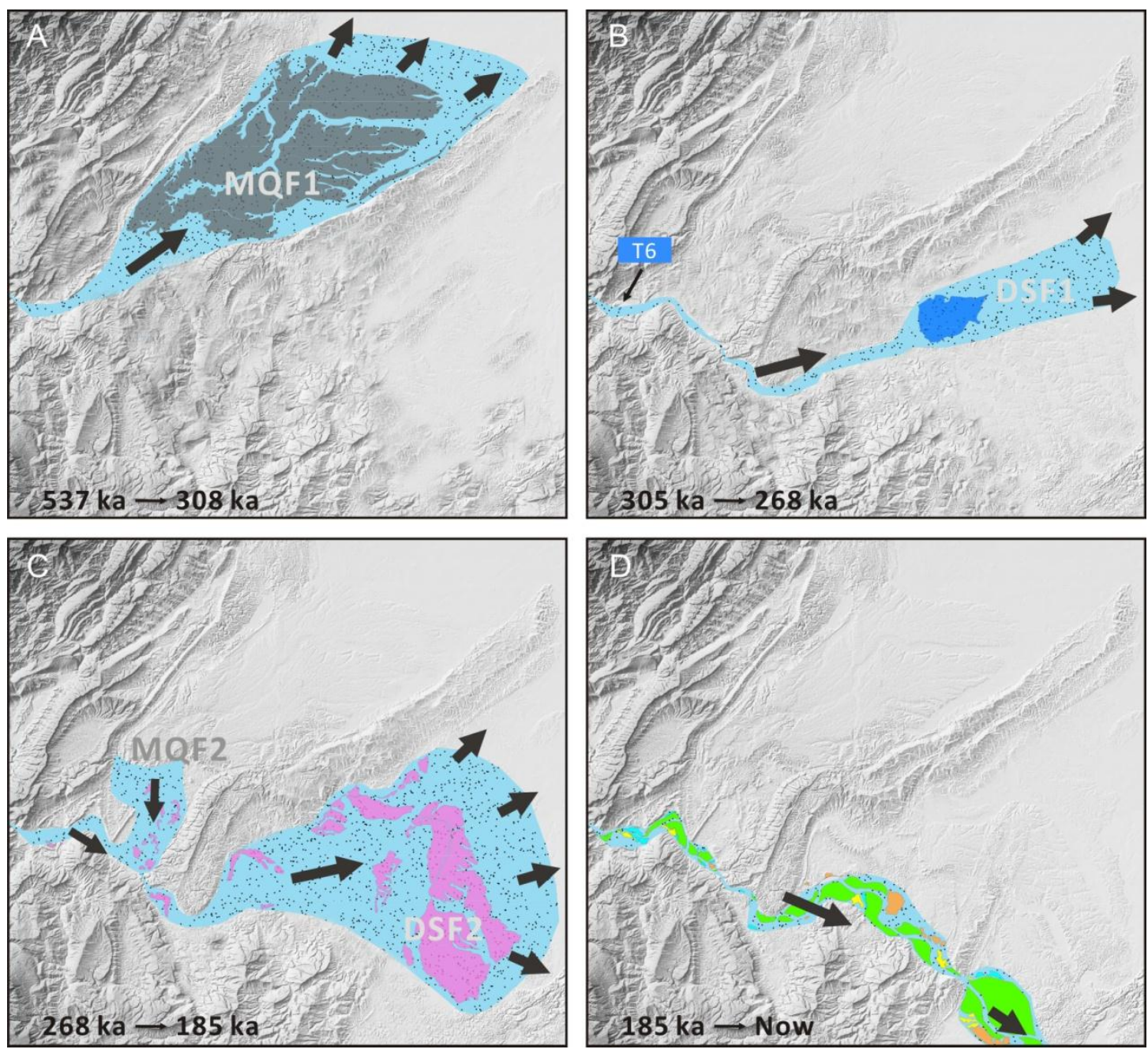

Fig. 10. Evolutionary process of the Qingyi River since the middle Pleistocene. The legends here are the same as those in Fig. 9.

\subsubsection{Significances of the geomorphological surface sequence}

To conduct detailed geomorphological research on the flexible evolution of river landforms is difficult, and previous studies have deemed that river terraces are the primary objects. However, 
research on river terraces is subject to substantial limitations. (i) In humid regions where erosion and weathering are rather strong, high terraces cannot be preserved effortlessly. (ii) Because the coverage of terraces is very limited, they can be analyzed only along a single river direction for application to structural studies. (iii) For extensive river terraces, no enough effective methods can be used to determine whether the geomorphological surfaces at all levels are corresponding. The purpose of this study was to present a geomorphological surface sequence by taking advantage of more ancient alluvial fans that have been abandoned; this sequence can reflect the evolution of the river and be used to judge the coverage of the river basins in various periods. In addition, distortions in the alluvial fan sectors and terrace surfaces can reflect tectonic activity, although a continuous geomorphological surface sequence can be utilized to effectively analyze the characteristics of the tectonic activity. Furthermore, a favorable inheritance temporally exists between the alluvial fans and terraces.

\subsection{Conclusions}

(1) Using measured geological sections, stratigraphic sections, and field elevation measurements, the inheritance relationship between the abandoned alluvial fans of the Qingyi River and the modern terrace has been determined; moreover, the data have been combined to establish a geomorphological surface sequence in the foreland region of Longmen Shan, eastern Tibetan Plateau. We can see that part of the alluvial fans were formed before the terraces of the modern Qingyi River. However, part of the alluvial fans took shape during the formation of T6 and T5, and a close relation exists between them. This geomorphological surface sequence reflects multiple migrations of the Qingyi River in the foreland of Longmen Shan since the middle Pleistocene and also can be applied to perform further research on tectonic problems. 
(2) In the river sediment samples that were collected at depths of $\sim 2 \mathrm{~m}$ from the surface, the geomorphological surfaces of the various levels were effectively distinguished from one another based on the sediments' degree of weathering, as reflected in the major elements and particle size tests. The sediments were intuitively represented in CIA, A-CN-K, and Pettijohn and Herron lithology classification figures to show weathering diversities. Especially within the range of 300 $\mathrm{ka}$, we can obviously see that the degree of weathering of the ancient river sediments increased over time, which indicates that weathering can play a significant role in studies of ancient river sediments and should be further probed in subsequent research.

(3) Based on detailed and effective analyses, the distribution of the ancient geomorphological surfaces effectively reflects the evolutionary processes of the ancient river. The formation process of the geomorphological surfaces from most ancient to most recent have been determined: $\mathrm{MQF1} \rightarrow$ Qingyi River T6 / DSF1 $\rightarrow$ Qingyi River T5 / DSF2 / MQF2 $\rightarrow$ Qingyi River T4 $\rightarrow$ T3 $\rightarrow$ $\mathrm{T} 2 \rightarrow \mathrm{T} 1$, in which MQF stands for the Mingshan-Qionglai alluvial fan, and DSF stands for the Danling-Simeng alluvial fan. The geomorphological surfaces in the different periods recorded the positions where the rivers flowed and the ancient elevations.

(4)Since the middle Pleistocene, the Qingyi River has been significantly rechanneled twice. The first rechannelization $(537 \sim 308 \mathrm{ka})$ cut through the Xiongpo anticline (XPA) and formed the abandoned Mingshan-Qionglai alluvial fan (MQF), and the second (268 ka $185 \mathrm{ka}$ ) cut through the Sansuchang anticline (SSCA) and formed the abandoned Danling-Simeng alluvial fan (DSF). Moreover, the Qingyi River terrace corresponds to those two episodes of rechannelization.

(5) Since the middle Pleistocene, the foreland region on the southern section of Longmen Shan has always been active, which affected the migrations of rivers in this region and controlled the 
distribution of the ancient river geomorphological surfaces. The tectonic activity can be further analyzed through research on the alluvial fan sectors and terraces.

\section{Acknowledgements}

Thank you so much for the enlightening comments from the referees, and the detailed modifications from the editor. This study was supported by the National Science Foundation of China (grant number 41272234) and Research Fund of Institute of Crustal Dynamics, China Earthquake Administration (grant number ZDJ 2009-1). 


\section{Referrence}

Bagnold R.A., Barndorff N.O., 1980. The pattern of natural size distributions. Sedimentology. 27 (2), $199-207$.

Bahlburg H., Dobrzinski N., 2011. A review of the Chemical Index of Alteration (CIA) and its application to the study of Neoproterozoic glacial deposits and climate transitions. Geol. Soc., London, Memoirs. 36 (1), 81-92.

Burbank D.W., Anderson R.S., 2011. Tectonic geomorphology, 2nd ed. Wiley Blackwell Publishing, Chichester. pp. 197-202

Burbank D.W., Beck R.A., Raynolds R. et al, 1988. Thrusting and gravel progradation in foreland basins, a test of post-thrusting gravel dispersal. Geology. 16 (12), 1143-1146.

Burbank D.W., Leland J., Fielding E. et al., 1996. Bedrock incision, rock uplift and threshold hillslopes in the northwestern Himalayas. Nature. 379 (6565), 505-510.

Caceres L.M., Olias M., Andres J.R. et al., 2013. Geochemistry of Quaternary sediments in terraces of the Tinto River (SW Spain): Paleoenvironmental implications. Catena. 101, 1-10.

Canfield D.E., 1997. The geochemistry of river particulates from the continental USA: major elements. Geochim. Cosmochim. Ac. 61 (16), 3349-3365.

Chen J., Ji J., 1997. The geological chemistry research about the weathering of Luochuan loess. Sci.

China. Earth. Sci. 27 (6), 531-536. (in Chinese)

Cui Z Q, Liu D Z, Meng Q M., 2009. The origin of the Pleistocene gravel in western Sichuan depression. Geol. China. 5, 1065-1078. (in Chinese)

Davis R.A., 1983. Depositional systems: A genetic approach to sedimentary geology. Englewood Cliffs, Prentice Hall. pp. 210-217 
Decelles P.G., Giles K.A., 1996. Foreland basin systems. Basin. Res. 8 (2), 105-123.

Deng L., 2009. Research of the characteristics of Quanternary sediments and sedimentary enviroments in Mingshan area, Sichuan. Master's Thesis. Chengdu. Univ. of Technol. (in Chinese)

England P., Molnar P., 1990. Surface uplift, uplift of rocks, and exhumation of rocks. Geology. 18 (12), 1173-1177.

Feng L., Chu X., Zhang Q., 2003. CIA (chemical index of alteration) and its applications in the Neoproterozoic clastic rocks. Front. Earth. Sci. 10 (4), 539-544.

Folk R.L., 1966. A review of grain-size parameters. Sedimentology. 6 (2), 73-93.

Guo X., Gao R., Randy K. G. et al., 2013. Imaging the crustal structure beneath the eastern Tibetan Plateau and implications for the uplift of the Longmen Shan range. Earth. Planet. Sc. Lett. 379, $72-80$.

Harvey A.M., Mather A.E., Stokes M.R., 2005. Alluvial fans: geomorphology, sedimentology, dynamics. Geol. Soci. Publishing. pp.133-152.

He Z., Ma B., 2015. Holocene paleoearthquakes of the Daqingshan fault detected from knickpoint identification and alluvial soil profile. J. Asian. Earth. Sci. 98 (2015): 261-271.

Herron M.M., 1988. Geochemical classification of terrigenous sands and shales from core or log data. J. of Sediment. Res. 58 (5), 820-829.

Horton B.K., Decelles P.G., 2001. Modern and ancient fluvial megafans in the foreland basin system of the central Andes, southern Bolivia: implications for drainage network evolution in fold-thrust belts. Basin Res. 13 (1), 43-63.

Hubbard J., Shaw J.H., 2009. Uplift of the Longmen Shan and Tibetan plateau, and the 2008 Wenchuan $(\mathrm{Ms}=7.9)$ earthquake. Nature. $458(7235), 194-197$. 
Huggett R J., 2007. Fundamentals of geomorphology, 3rd ed. Routledge, Taylor and Francis Group. New York. pp.229-231.

Jia D., Li Y., Lin A. et al., 2010. Structural model of 2008 Mw 7.9 Wenchuan earthquake in the rejuvenated Longmen Shan thrust belt, China. Tectonophysics. 491 (1-4), 174-184.

Johnsson M.J., Stallard R.F., Lundberg N., 1991. Controls on the composition of fluvial sands from a tropical weathering environment: sands of the orinoco river drainage basin, Venezuela and Colombia. Geol. Soc. Am. Bull. 103 (12), 1622-1647.

Lavé J., Avouac J.P., 2000. Active folding of fluvial terraces across the Siwaliks Hills, Himalayas of central Nepal. J. Geophys. Res., Solid Earth, 105 (B3), 5735-5770.

Li K., Xu X., Tan X. et al., 2015. Late Quaternary deformation of the Longquan anticline in the Longmen Shan thrust belt, eastern Tibet, and its tectonic implication. J. Asian. Earth. Sci. $112(2015) 1-10$

Li X., Yang D., Lu H., 1999. Oxide geochemistry features and paleoclimatic record of the Aeolian dust depositional sequence in southern Anhui. Mar. Geol. Quanternary. Geol. 19 (04), 75-82. (in Chinese)

Li X., Han Z., Yang S. et al., 2007. Chemical weathering intensity and element migration features of the Xiashu Loess profile in Zhenjiang. Acta Geographica Sinica. 62 (11), 1174-1184. (in Chinese)

Li Y., Jia D., Shaw J.H. et al., 2010. Structural interpretation of the coseismic faults of the Wenchuan earthquake: Three dimensional modeling of the Longmen Shan fold-and-thrust belt. J. Geophys. Res. 115, 1-26.

Liu S., Zhang S., Ding R., et al., 2015. Upper crustal folding of the 2013 Lushan earthquake area in southern Longmen Shan, China: insights from Late Quaternary fluvial terraces. Tectonophysics. 
639, 99-108.

Liu Z., Zhao Y., Colin C. et al., 2009. Chemical weathering in Luzon, Philippines from clay mineralogy and major-element geochemistry of river sediments. Appl. Geochem. 24 (11), $2195-2205$

Ma B., Su G., Hou Z. et al., 2005. Late Quanternary slip rate in the central part of the Longmen Shan fault zone from terrace deformation along the Minjiang river. Seismol. Geol. 27 (02), 234-242. (in Chinese)

Mclennan S.M., 1993. Weathering and global denudation. J. Geol. pp. 295-303.

Mclennan S.M., 1995. Sediments and soils: chemistry and abundances. Rock Physics and Phase Relations: A Handbook of Physical Constants. 8-19.

Miller W., Baharuddin M., 1987. Particle size of interrill-eroded sediments from highly weathered soils. Soil. Sci. Soc. Am. J. 51 (6), 1610-1615.

Munsell color, 2013. Munsell soil color book, 2009 year revised. Grand Rapids.

Nesbitt H.W., Markovics G., 1980. Chemical processes affecting alkalis and alkaline earths during continental weathering. Geochim. Cosmochim. A. 44 (11), 1659-1666.

Nesbitt H.W., Young G.M., 1982. Early proterozoic climates and plate motions inferred from major element chemistry of Lutites. Nature. 299 (5885), 715-717.

Nesbitt H.W., Young G.M., 1984. Prediction of some weathering trends of plutonic and volcanic rocks based on thermodynamic and kinetic considerations. Geochim. Cosmochim. Ac. 48 (7), $1523-1534$.

Nesbitt H.W., Young G.M., 1989. Formation and diagenesis of weathering profiles. J. Geol. 97 (2), 129-147. 
Nesbitt H.W., Young G.M., Mclennan S.M. et al., 1996. Effects of chemical weathering and sorting on the petrogenesis of siliciclastic sediments, with implications for provenance studies. J. Geol. $525-542$.

Oldfield F., Maher B., Donoghue J. et al., 1985. Particle-size related, mineral magnetic source sediment linkages in the Rhode River catchment, Maryland, USA. J. Geol. Soc. 142 (6), 1035-1046.

Ota Y., Lin Y., Chen Y. et al., 2009. Touhuanping Fault, an active wrench fault within fold-and-thrust belt in northwestern Taiwan, documented by spatial analysis of fluvial terraces. Tectonophysics. $474(3-4), 559-570$.

Pan B.T., Burbank D., Wang Y. et al., 2003. A 900 ky record of strath terrace formation during glacial-interglacial transitions in northwest China. Geology. 31 (11), 957-960.

Parsons T., Ji C., Kirby E., 2008. Stress changes from the 2008 Wenchuan earthquake and increased hazard in the Sichuan basin. Nature. 454 (7203), 509-510.

Pettijohn F.J., Potter P.E., Siever R., 1973. Sand and sandstone. Springer Science and Business Media. pp. 392-397.

Poisson B., Avouac J.P., 2004. Holocene hydrological changes inferred from alluvial stream entrenchment in North Tian Shan (Northwestern China). J. Geol. 112 (2), 231-249.

Potter P.E., 1978. Petrology and chemistry of modern big river sands. J. Geol. 423-449.

Roddaz M., Viers J., Brusset S. et al., 2006. Controls on weathering and provenance in the Amazonian foreland basin: Insights from major and trace element geochemistry of Neogene Amazonian sediments. Chem. Geol. 226 (1-2), 31-65.

Sahu B.K., 1964. Depositional mechanisms from the size analysis of clastic sediments. J. Sediment. Res. 34 (1). 
Singh M., Sharma M., Tobschall H.J., 2005. Weathering of the Ganga alluvial plain, northern India: implications from fluvial geochemistry of the Gomati River. Appl. Geochem. 20 (1), 1-21.

Singh P., 2009. Major, trace and REE geochemistry of the Ganga River sediments: Influence of provenance and sedimentary processes. Chem Geol. 266 (3-4), 242-255.

Tang X., Tao X., 2009. Analysis on characteristics of Qingyi River Quanternary terrace in Yaan area. Acta Sedimentologica Sinica. 27 (1),137-141. (in Chinese)

Taylor S.R., mclennan S.M., 1985. The continental crust: its composition and evolution, Blackwell Scientific Publishing. London.

Viseras C., Calvache M.L., Soria J M, et al., 2003. Differential features of alluvial fans controlled by tectonic or eustatic accommodation space. Examples from the Betic Cordillera, Spain. Geomorphology. 50 (02), 181-202.

Vital H., Stattegger K., 2000. Major and trace elements of stream sediments from the lowermost Amazon River. Chem. Geol. 168 (1), 151-168.

Xu X., Wen X., Yu G. et al., 2009. Coseismic reverse and oblique slip surface faulting generated by the 2008 Mw 7.9 Wenchuan earthquake, China. Geology. 37 (6), 515-518.

Ying L., Liang B., Wang Q., et al., 2012. Major elements characters of the middle Pleistocene Vermicular Red Clay from the Western Sichuan Plain. Geol. J. China. Univ. 18 (4), 759-764. (in Chinese)

Yuan J., Tao X., 2008. The Features of Gravel Bed and Drainage Evolution in the Qingyi River Valley in the Mingshan-Danling Region, Sichuan. Acta Geologica Sinica. 28 (1), 6-12. (in Chinese)

Zhang P., 2013. A review on active tectonics and deep crustal processes of the Western Sichuan region, eastern margin of the Tibetan Plateau. Tectonophysics. 584 (SI), 7-22. 
Zhang P., Wen X., Shen Z. et al., 2010. Oblique, high-angle, listric reverse faulting and associated development of strain: The Wenchnan earthquake of May 12, 2008, Sichuan, China, Annu. Rev. Earth. and Pl. Sci. 353-382.

Zhang S., Ding R., Mao C. et al, 2010. Morphological Appearance of the Longmenshan Tectonic Uplift on the Eastern Margin of Tibetan Plateau. Quaternary Sci. 30 (4), 791-802. (in Chinese)

Zhang Z., Chen X., Liu S., 1982. Cause of Mingqiong upland, forming age and river diversions. Geol. Bull. Sichuan. (02), 101-102. (in Chinese)

Zhang Z., Chen X., Liu S. et al, 2000. Origin and geological age of the Daleng-Simeng gravel bed. J. Mt. Sci. (S1), 8-16. (in Chinese)

Zhang Z., Wang Y., Chen Y. et al., 2009. Crustal structure across Longmenshan fault belt from passive source seismic profiling. Geophys. Res. Lett. 36 (L17310), 1-4. 